\title{
WATER QUALITY IN THE E. A. PATTERSON LAKE BASIN, NORTH DAKOTA, JUNE 1995 THROUGH MAY 1996
}

By Kathleen M. Macek-Rowland

U.S. GEOLOGICAL SURVEY

Water-Resources Investigations Report 97-4215

Prepared in cooperation with the CITY OF DICKINSON, NORTH DAKOTA, and the NORTH DAKOTA DEPARTMENT OF HEALTH

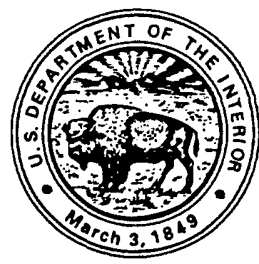




\title{
U.S. DEPARTMENT OF THE INTERIOR BRUCE BABBITT, Secretary
}

\author{
U.S. GEOLOGICAL SURVEY \\ MARK SCHAEFER, Acting Director
}

Any use of trade, product, or firm names is for descriptive purposes only and does not imply endorsement by the U.S. Government.

For additional information write to:

District Chief

U.S. Geological Survey

Water Resources Division

821 East Interstate Avenue

Bismarck, ND 58501-1199
Copies of this report can be

purchased from:

U.S. Geological Survey

Branch of Information Services

Box 25286

Denver, CO 80225-0286 


\section{CONTENTS}

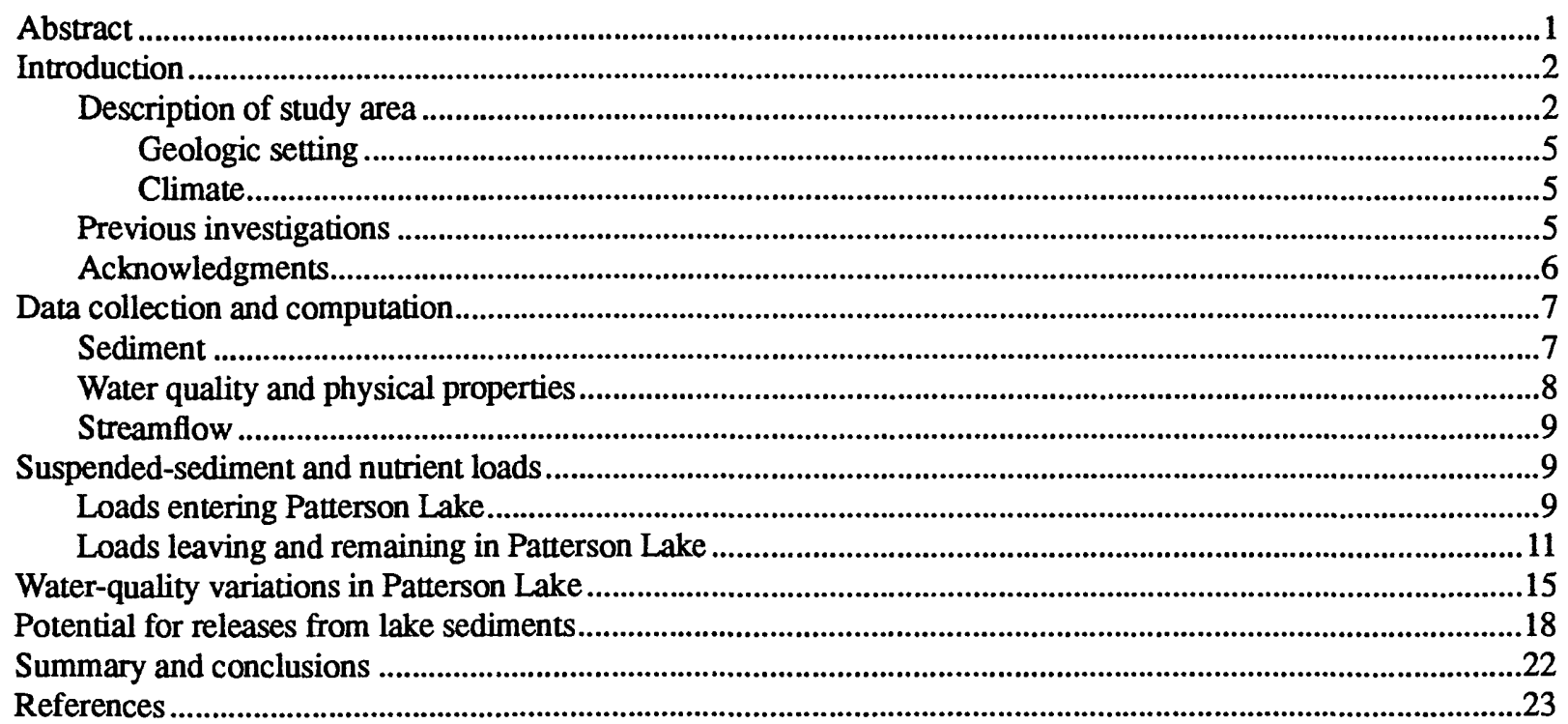

\section{FIGURES}

1. Map showing location of study area, southwestern North Dakota, and tributary and outflow sites .....................3

2. Map showing location of lake sites on E. A. Patterson Lake ...............................................................................4

3. Graph showing average monthly precipitation for 1949-94, monthly precipitation for January through December 1995, and monthly precipitation for January through May 1996 at the Dickinson Municipal Airport

\section{TABLES}

1. Drainage area, runoff, and suspended-sediment load for basins within the E. A. Patterson Lake Basin, June 1995 through May 1996

2. Percent of suspended sediment less than 0.062 millimeter in particle size in selected samples collected from tributary and outflow sites, June 1995 through May 1996

3. Particle-size distribution in bed-sediment samples collected from tributary sites, September 20, 1995.............13

4. Drainage area and total nutrient load for basins within the E. A. Patterson Lake Basin, June 1995 through May 1996.

5. Particle-size distribution in bed-sediment samples collected from lake sites, July 20,1995 .............................16

6. Depth profiles of physical properties at lake sites, June 1995 through May 1996 ...........................................17

7. Concentrations of selected water-quality constituents in samples collected from lake sites, June 1995 through May 1996.

8. Concentrations of selected water-quality constituents in elutriate and bottom-water samples collected from lake sites, July 20, 1995. 


\title{
Water Quality in the E. A. Patterson Lake Basin, North Dakota, June 1995 through May 1996
}

\author{
By Kathleen M. Macek-Rowland
}

\begin{abstract}
During June 1995 through May 1996, sediment, water-quality, physical-property, and streamflow data were collected from selected sites located in the E. A. Patterson Lake Basin. Specific objectives were to determine the suspended-sediment and total nutrient loads in major tributaries to Patterson Lake, including the loads entering, leaving, and remaining in the lake; determine the water-quality variations in Patterson Lake during the year; and evaluate the potential for nutrients and selected ions in lake sediments to be released back into lake waters.

The total suspended-sediment load leaving Patterson Lake was 7,120 tons per year, and the load remaining was 13,000 tons per year. Most of the suspended sediment in tributaries to Patterson Lake was silt and clay. The total nitrogen load entering the lake was 41.02 tons per year, the load leaving was 39.46 tons per year, and the load remaining was 1.56 tons per year. The total phosphorus load entering the lake was 11.85 tons per year, the load leaving was 5.57 tons per year, and the load remaining was 6.28 tons per year.
\end{abstract}

Water-quality variations occurred in Patterson Lake during the year. Specific-conductance values decreased substantially from August to September 1995, indicating a dilution of the lake from runoff. $\mathrm{pH}$ values ranged from 6.7 to 8.4 and varied little among sites. Water temperatures reflected strong seasonal variability. The largest variation occurred during June 1995 in the deepest part of the lake, indicating that the lake was stratified with regard to temperature.

Dissolved-oxygen concentrations near the lake bottom were less than 5 milligrams per liter during June and July and greater than or equal to 5 milligrams per liter during the remainder of the year. Secchi-disk transparency ranged from 1.2 to 27 inches. The smallest values occurred during June and July 1995, which was when biomass material and sediment were visually observed in the lake. Chlorophyll $a$ concentrations generally were larger during July and August and varied little among sites.

The analyses of the elutriate samples indicated a large increase in ammonia concentrations in the bed sediment. The potential exists for more ammonia to be added to the lake if the bottom sediments become mixed with lake water. There is the potential for other constituents to increase or decrease if the bottom sediments become mixed with the lake water, but these changes are not as significant as the ammonia increase. The increase in ammonia is important because, at times, the limited availability of nitrogen can limit algae growth in the lake; thus, additional nitrogen (in the form of ammonia) may increase algae production. 


\section{INTRODUCTION}

E. A. Patterson Lake (Patterson Lake) is located southwest of Dickinson, North Dakota, in Stark County (fig. 1). The lake is the result of a dam constructed on the Heart River in 1949 by the Bureau of Reclamation. The dam was constructed to provide for a municipal water supply, irrigation, flood control, and water-based recreation in the southwestern part of the State. A 1991 survey indicated that the total storage capacity of the lake is 8,612 acre-feet. The surface area of the lake is 1,194 acres at the spillway elevation of 2,420 feet above sea level ${ }^{1}$. Depths in the lake range from a few feet in the marshy area in the west to about 30 feet near the spillway in the east. In 1992, the city of Dickinson converted to the newlyconstructed Southwest Water Pipeline for its municipal water supply and retained the lake as a back-up water supply for emergencies.

Since construction of the dam, sedimentation and nutrient loading in the lake have caused many problems. Sedimentation has caused areas in the lake to become more shallow, and excessive sedimentation and nutrient loading have limited fish production and caused excessive algal blooms. The city of Dickinson has incurred additional water-treatment costs because large phytoplankton concentrations have affected the odor and taste of the water. These problems have concerned local citizens as well as local and State officials. In addition, the city of Dickinson and local groups are interested in maintaining the lake as a viable resource and attraction. Therefore, a better understanding of Patterson Lake and its watershed is needed so the city of Dickinson and others can make management decisions that will improve lake conditions.

During June 1995 through May 1996, the U. S. Geological Survey (USGS) conducted a study in cooperation with the city of Dickinson and the North Dakota Department of Health (NDDH) to determine the water quality in the Patterson Lake Basin. The study focused mainly on the amount of sedimentation and nutrient loading in the lake. Specific objectives were (1) to determine the suspended-sediment and total nutrient loads in major tributaries to Patterson Lake, including the loads entering, leaving, and remaining in the lake; (2) to determine the water-quality variations in Patterson Lake during the year; and (3) to evaluate the potential for nutrients and selected ions in lake sediments to be released back into lake waters.

The study area consists of the Patterson Lake Basin (fig. 1). Data were collected from five sites located on tributaries to Patterson Lake (fig. 1), from one site located near the outflow of Patterson Lake (fig. 1), and from three sites located on Patterson Lake (fig. 2). During periods of rainfall and snowmelt runoff, data were collected more frequently from the sites located on tributaries. This report presents the results of the study.

\section{Descriptlon of Study Area}

The study area, which encompasses 409 square miles in parts of Billings and Stark Counties in southwestern North Dakota, consists of the Patterson Lake Basin and includes the headwaters of the Heart River and its tributaries. The Patterson Lake Basin has a fairly well-integrated drainage system with wellformed valleys, low stream gradients, and meandering streams (Maderak, 1966). The basin is located in an

\footnotetext{
${ }^{1}$ In this report, "sea level" refers to the National Geodetic Vertical Datum of 1929 (NGVD of 1929)--a geodetic datum derived from a general adjustment of the first-order level nets of both the United States and Canada, formerly called Sea Level Datum of 1929.
} 


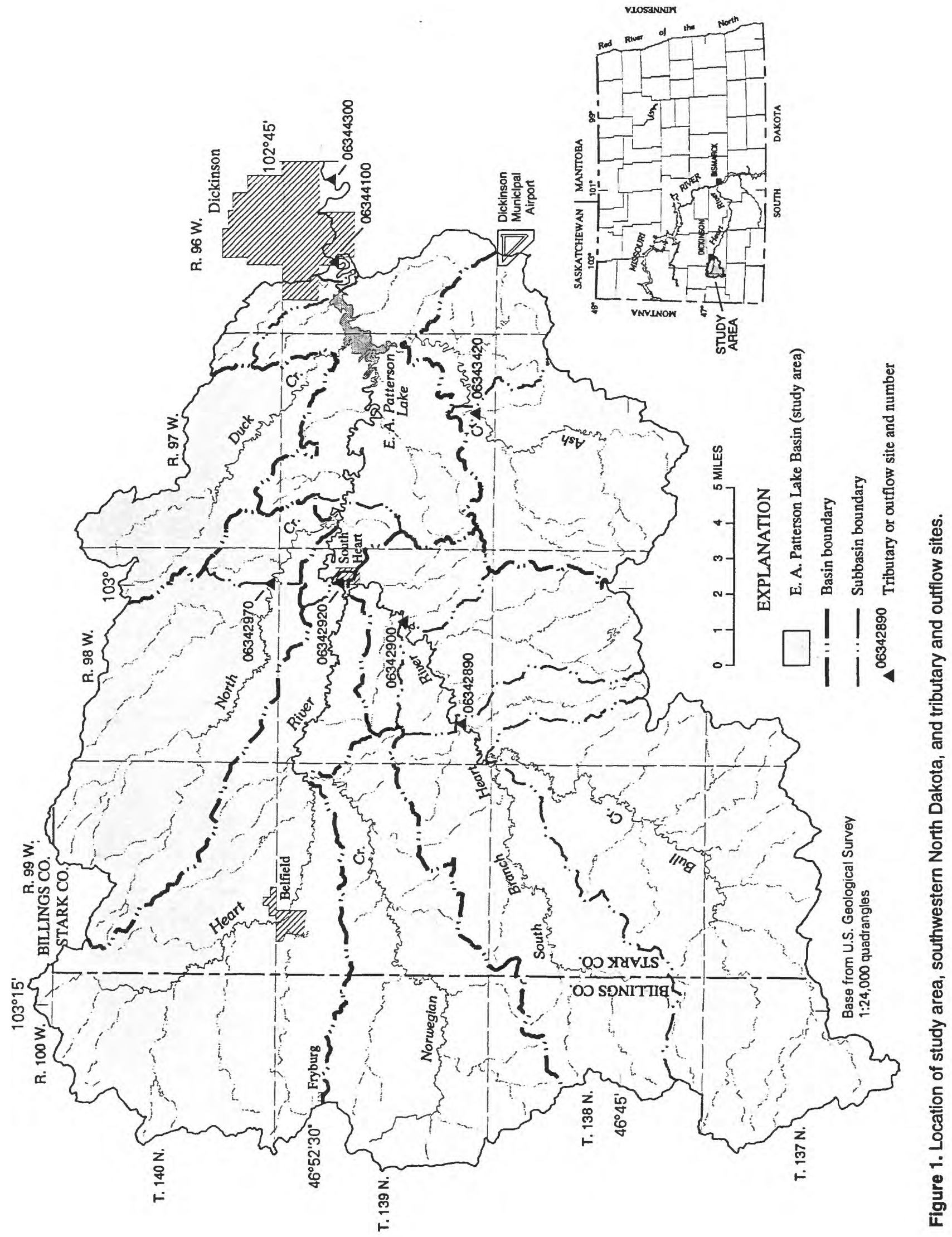




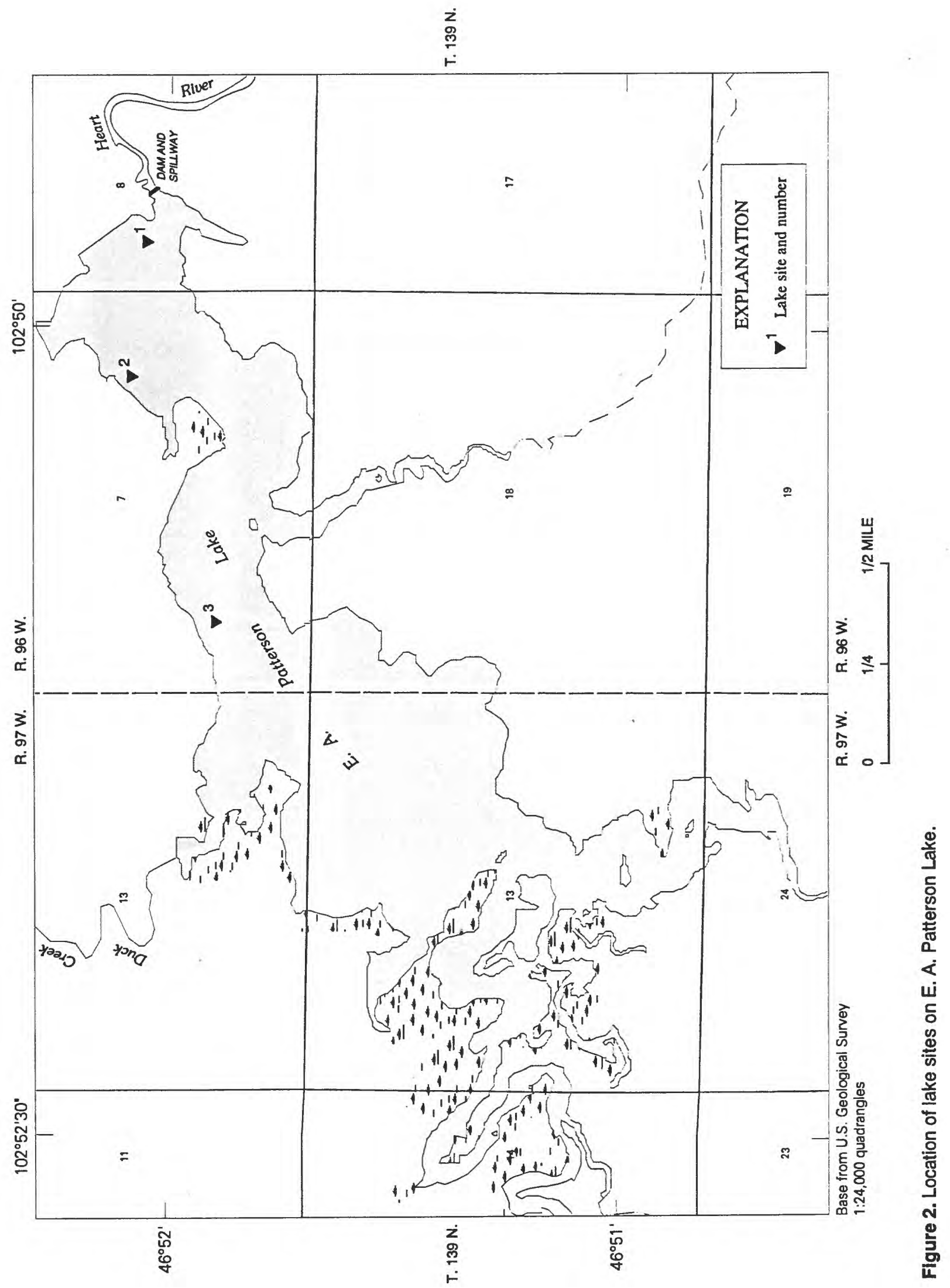


unglaciated plateau that consists of rolling topography occasionally broken by buttes except for an area of badlands located near South Heart.

Dickinson, which has a population of 16,190 (North Dakota State Data Center, written commun., 1994), is located northeast of Patterson Lake. South Heart, which has a population of 324; Belfield, which has a population of 874; and Fryburg, which is unincorporated (no population given), are located west of Patterson Lake (fig. 1). Land use in the Patterson Lake Basin primarily is cropland and rangeland. Since construction of the dam, several crops in the basin have been irrigated by surface water. In recent years, oil well development has increased in and around the basin.

\section{Geologic Setting}

The Patterson Lake Basin is located on the south-central flank of the Williston Basin, which is a broad structural depression that contains sedimentary rocks of Cambrian to Quaternary age. These sedimentary rocks consist of sandstones, shales, carbonates, and evaporites. Predominate outcrops in the Patterson Lake Basin consist of Tertiary-age rocks of the Fort Union Formation in the northern part of the basin and the Golden Valley and White River Formations in the southern part of the basin. These outcrops may be sources of sediment to the Heart River and its tributaries. Some undifferentiated drift and alluvium from the Quaternary age are found in a part of the Heart River Valley within the basin. The drift and alluvium deposits are composed of clay, silt, sand, and gravel and may contribute sediment to the Heart River if exposed as banks along the river channel.

The Fort Union Formation consists of shales, sandstones, lignites, and some limestones; the Golden Valley Formation consists of claystones and interbedded siltstones and sandstones; and the White River Formation consists of calcareous shales, sandstones, and thin limestones. The area of badlands located near South Heart is carved from the Golden Valley Formation. Outcrops of the Fort Union, Golden Valley, and White River Formations, particularly those in the form of buttes or hills, are vulnerable to erosion because of limited vegetation in the area and the effect of rainwash on exposed surface areas. The erosion of buttes and hills can be exacerbated by overgrazing and drought conditions, which reduce vegetative cover. During 1988-92, the entire State experienced the second most severe drought since the 1930's (Williams-Sether and others, 1994).

\section{Climate}

The semiarid climate in the Patterson Lake Basin is characterized by long, cold winters and by short, warm summers that have brief but intense rainstorms. Average annual precipitation at the Dickinson Municipal Airport during 1949-94 was 15.78 inches (U.S. Department of Commerce, National Oceanic and Atmospheric Administration, Environmental Data Service, 1950-97). During 1995, annual precipitation was 18.56 inches. The greatest rainfall events for the spring and summer occurred during late May, mid-July, and late August, causing above-normal runoff in the basins (fig. 3). During May through August 1995, precipitation was 15.24 inches, which was 167 percent greater than the average monthly precipitation of 9.12 inches for the same 4 months during 1949-94. Average annual snowfall for the area is about 35 inches and usually is melted by the end of March. During the study period, the greatest snowfalls in the Dickinson area occurred during both January and February 1996.

\section{Previous Investigations}

Maderak (1966) collected streamflow, water-quality, and sediment data from the Heart River Basin as part of a program for development of the Missouri River Basin. Haffield (1981) compiled statistical 


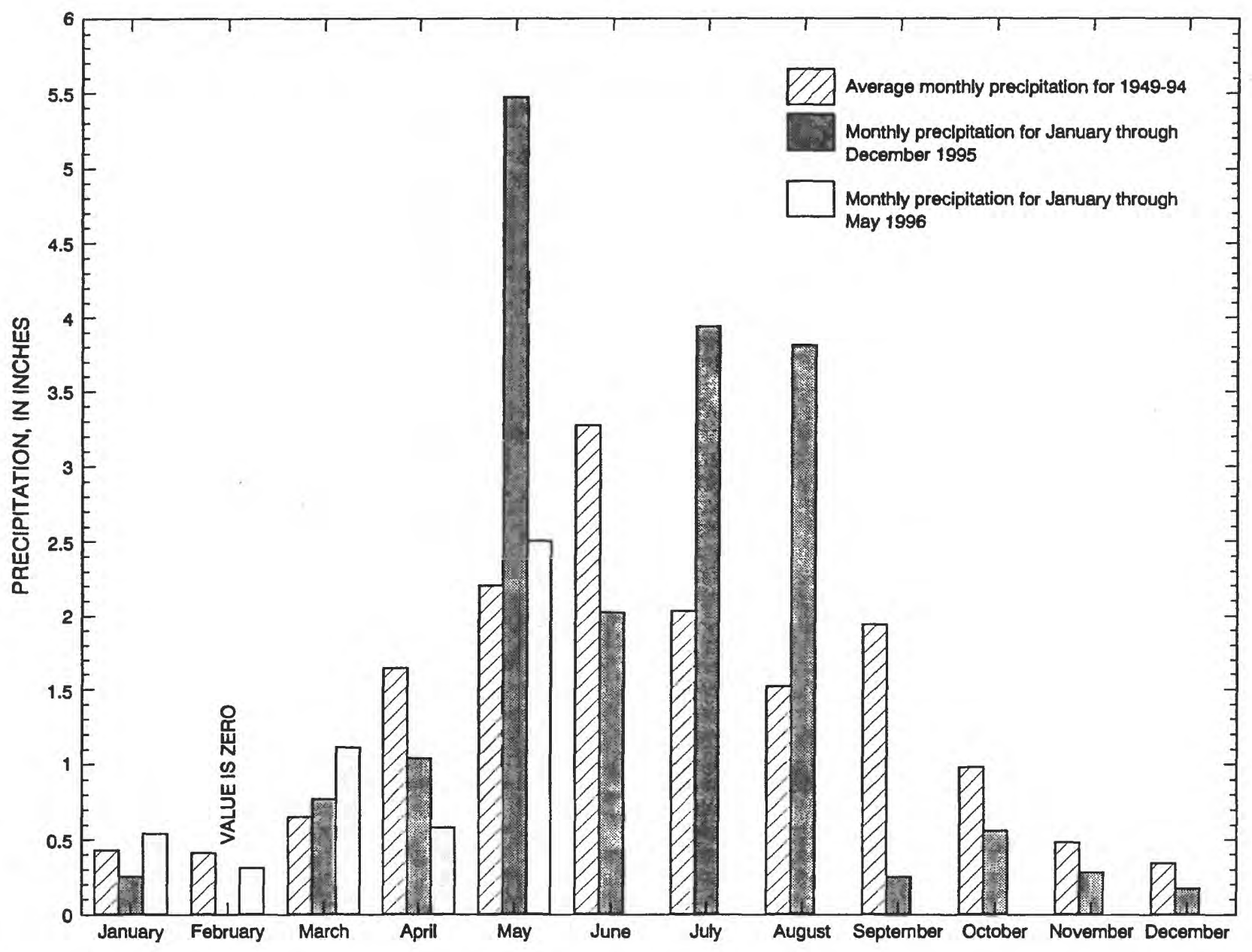

Figure 3. Average monthly precipitation for 1949-94, monthly precipitation for January through December 1995 , and monthly precipitation for January through May 1996 at the Dickinson Municipal Airport. (Data from U.S. Department of Commerce, National Oceanic and Atmospheric Administration, Environmental Data Service, 1950-97.)

summaries of streamflow and water-quality data collected during 1977-80 from 67 stations located in western North Dakota. Of these stations, three were located in the Patterson Lake Basin. The Bureau of Reclamation (written commun., 1991) calculated area-capacity tables for Patterson Lake from a sedimentation survey conducted in 1991 by the U.S. Soil Conservation Service. The Dickinson Area Chamber of Commerce (written commun., 1995) compiled an executive summary that lists studies of Patterson Lake completed during 1951-95. Many of the studies listed in the summary were fish and wildlife studies and water-quality monitoring studies. Lest (1995) reported results of an investigation of changes in Patterson Lake after 41 years of reservoir-sediment accumulation. The results were based on the sedimentation survey conducted in 1991 by the U.S. Soil Conservation Service.

\section{Acknowledgments}

The USGS acknowledges Roger (Skip) Rapp of the city of Dickinson and his staff for assistance in collecting sediment data and the Western Soil Conservation District, the North Dakota Game and Fish Department, and the Stark County Water Resource Board for technical assistance. The USGS also acknowledges the residents of the Patterson Lake Basin for allowing access to their property for data collection. 


\section{DATA COLLECTION AND COMPUTATION}

During June 1995 through May 1996, data were collected to describe the seasonal hydrologic and water-quality variability occurring throughout the basin and within the lake. Sediment, water-quality, physical-property (specific conductance, $\mathrm{pH}$, temperature, and dissolved oxygen), and streamflow data were collected from five sites located on tributaries to Patterson Lake and one site located near the outflow site of Patterson Lake (fig. 1). The tributary sites are South Branch Heart River below Bull Creek (06342890), South Branch Heart River near South Heart (06342900), Heart River at South Heart (06342920), North Creek near South Heart (06342970), and Ash Creek near South Heart (06343420); and the outflow site is Heart River at State Avenue in Dickinson (06344100). Streamflow data were collected from the continuous-record gaging station, Heart River at Dickinson (06344300), located downstream from the outflow site (fig. 1), when flow at the outflow site was too low for data collection. Sediment, water-quality, and physical-property data were collected from three sites (sites 1,2 , and 3 ) located on Patterson Lake (fig. 2). These lake sites previously were monitored by the NDDH and are identified in laboratory analyses as sites USGS 465202102495200 and NDDH 380865 (site 1), USGS 465201102500800 and NDDH 380866 (site 2), and USGS 465152102505700 and NDDH 380867 (site 3).

\section{Sediment}

Single vertical and multiple vertical water samples were collected from the five tributary sites and the outflow site and analyzed for suspended-sediment concentration. The samples were collected during three major rainfall runoff events (June 2-3, 1995; July 12-14, 1995; and August 23-25, 1995) and one snowmelt runoff event (March 11-14, 1996).

The single vertical samples were collected by observers (city of Dickinson employees). The samples were collected from each site at a fixed location in the stream. During low flow, the samples were collected using a depth-integrating technique and a US DH-48 sampler (Guy and Norman, 1970). Lowflow samples were collected once a week or daily depending on the turbidity of the stream water. During high flow, the samples were collected using a depth-integrating technique and a US D-74 sampler attached to a bridge or culvert. High-flow samples were collected more than once a day.

The multiple vertical samples were collected by USGS employees. The samples were collected from 10 to 20 locations along a stream cross section each time streamflow was measured. Samples also were collected from the same locations where the single vertical samples were collected. During low flow, the samples were collected using an equal width increment (EWI) sampling technique and a US DH-48 sampler (Guy and Norman, 1970). During high flow, the samples were collected using the EWI technique and a US D-74AL sampler. Because streamflow was measured more often during high flow than during low flow, more samples were collected during high flow.

The single vertical and multiple vertical samples were analyzed at the USGS sediment laboratory in Iowa City, Iowa. The samples were analyzed for suspended-sediment concentration, and selected samples were analyzed for percent of suspended sediment less than 0.062 millimeter in particle size. Sediment less than 0.062 millimeter in particle size is defined as silt and clay. Analytical methods used at the sediment laboratory are described in Guy (1969).

During the study period, daily average suspended-sediment concentrations were estimated using procedures described in Porterfield (1972). When the USGS collected a multiple vertical sample, a single vertical sample also was collected by the observer. The observer collected the sample at a fixed location in the stream. Suspended-sediment concentrations in the two samples then were compared to determine any 
bias. If concentrations varied by more than 10 percent, those in the single vertical samples were adjusted to those in the more accurate multiple vertical samples. The adjusted concentrations then were used to * estimate daily average suspended-sediment concentrations. Annual suspended-sediment loads (June 1995 through May 1996) were calculated from daily average streamflow and daily average suspended-sediment concentrations.

Bed-sediment samples were collected from the five tributary sites and the three lake sites and were used to determine particle-size distribution of sediment in the streambeds and lakebeds. The streambed samples were collected using a US BM-54 sampler, and the lakebed samples were collected using a stainless-steel Ponar grab sampler.

The lakebed samples were split in the field. Part of the sample was analyzed for particle-size distribution and the other part was elutriated. The particle-size distributions were determined at the USGS sediment laboratory in Iowa City, Iowa, using methods described in Guy (1969), and the elutriate tests were performed at the NDDH laboratory in Bismarck, N. Dak. An elutriate test is used to determine the potential for lake sediments to release chemicals, such as nutrients, ions, and trace elements, into the lake water. The chemical composition of lake water near the lake bed is compared to the chemical composition of lake water mixed with bed sediment (elutriate). Differences between chemical concentrations in the two types of samples indicate the potential for lake sediments to release chemicals.

\section{Water Quallty and Physical Propertles}

Water samples were collected from the five tributary sites and the outflow site and analyzed for water quality and physical properties. The samples were collected by USGS personnel whenever streamflow was measured, and more samples were collected during high flow than during low flow. The water samples were collected from multiple verticals along a stream cross section using the EWI technique (Guy and Norman, 1970).

Water samples also were collected from the three lake sites and analyzed for water quality and physical properties. During open-water periods, the samples were collected monthly from sites 1 and 3. However, for site 2, the samples were collected only on July 20, 1995. The samples were collected from the lake surface and directly above the lakebed using a 1-meter-long Kemmerer bottle sampler. When the lake was thermally stratified, the samples also were collected from above and below the thermocline. A depth profile of physical properties was made each time samples were collected. The profile was made using a Hydrolab multimeter that was calibrated according to manufacturer's instructions before each use.

The water samples collected for water-quality data were analyzed at the NDDH laboratory using U.S. Environmental Protection Agency methods. Laboratory equipment and methods were quality assured using procedures outlined in the North Dakota State Department of Health Quality Assurance Manual (Mike Ell, NDDH, oral commun., 1996). About 10 percent of the samples sent to the NDDH laboratory were replicate quality-assurance samples or field blanks.

Daily average nutrient concentrations were estimated for each tributary and outflow site using analytical results from the water samples collected by USGS personnel. Annual nutrient loads were calculated from daily average streamflow and daily average nitrogen and phosphorus concentrations. 


\section{Streamflow}

Streamflow measurements were made at the five tributary sites and the outflow site according to methods described in Rantz and others (1982). During low flow, streamflow was measured using a pygmy meter, and, during high flow, streamflow was measured from bridges and culverts using an AA current meter. More streamflow measurements were made during high flow than during low flow. During the study period, no flow occurred intermittently at many of the sites.

Streamflow measurements were used to develop a rating curve (a curve relating river stage to river streamflow) for each of the tributary sites and the outflow site. The daily average streamflow was calculated using the rating curve and stage readings according to methods described in Rantz and others (1982).

\section{SUSPENDED-SEDIMENT AND NUTRIENT LOADS}

The drainage area of Patterson Lake is 405 square miles at the dam. The drainage area at the outflow site, Heart River at State Avenue in Dickinson, located a couple of miles downstream from the dam, is 409 square miles. For this study, the drainage area at the outflow site is considered to be the total drainage area of the Patterson Lake Basin (fig. 1). The area that was gaged and sampled for this study was 332 square miles or 81.2 percent of the area of the basin (table 1). The area that was not gaged or sampled for this study was 77 square miles or 18.8 percent of the area of the basin. For purposes of this study, contributions from the gaged area are considered to be total contributions to the lake.

Gaged sites in the Patterson Lake Basin include the upper reach of the Heart River and three of its tributaries. These tributaries are South Branch Heart River, North Creek, and Ash Creek. The South Branch Heart River enters the Heart River above the Heart River at South Heart site, and North Creek and Ash Creek enter the Heart River downstream from the Heart River at South Heart site. The South Branch Heart River was gaged and sampled at two successive sites along its reach. These sites are South Branch Heart River below Bull Creek and South Branch Heart River near South Heart.

Suspended-sediment and nutrient loads in the Patterson Lake Basin were calculated for June 1995 through May 1996. Runoff from the gaged basins during this period ranged from 0.85 to 1.10 inches. During November 1983 through October 1995, average annual runoff at the Heart River at Dickinson continuous-record gaging station was 0.49 inch (Harkness and others, 1996). Although this station encompasses a larger drainage area than the study area, the considerably smaller average annual runoff from the station indicates greater-than-normal runoff occurred in the Patterson Lake Basin during June 1995 through May 1996.

\section{Loads Entering Patterson Lake}

During the study period, the total suspended-sediment load entering Patterson Lake was 20,120 tons per year (table 1). Heart River at South Heart contributed 17,500 tons per year (87 percent) to the total suspended-sediment load entering the lake. Of the 17,500 tons per year, South Branch Heart River near South Heart contributed 15,400 tons per year (88 percent); and of the 15,400 tons per year, South Branch Heart River below Bull Creek contributed 12,100 tons per year (79 percent). Thus, the South Branch Heart River below Bull Creek Basin contributed about 60 percent of the total suspended-sediment load entering Patterson Lake. The suspended-sediment yield for the South Branch Heart River near South Heart Basin was almost twice as much as the yield for the Heart River at South Heart Basin and much 


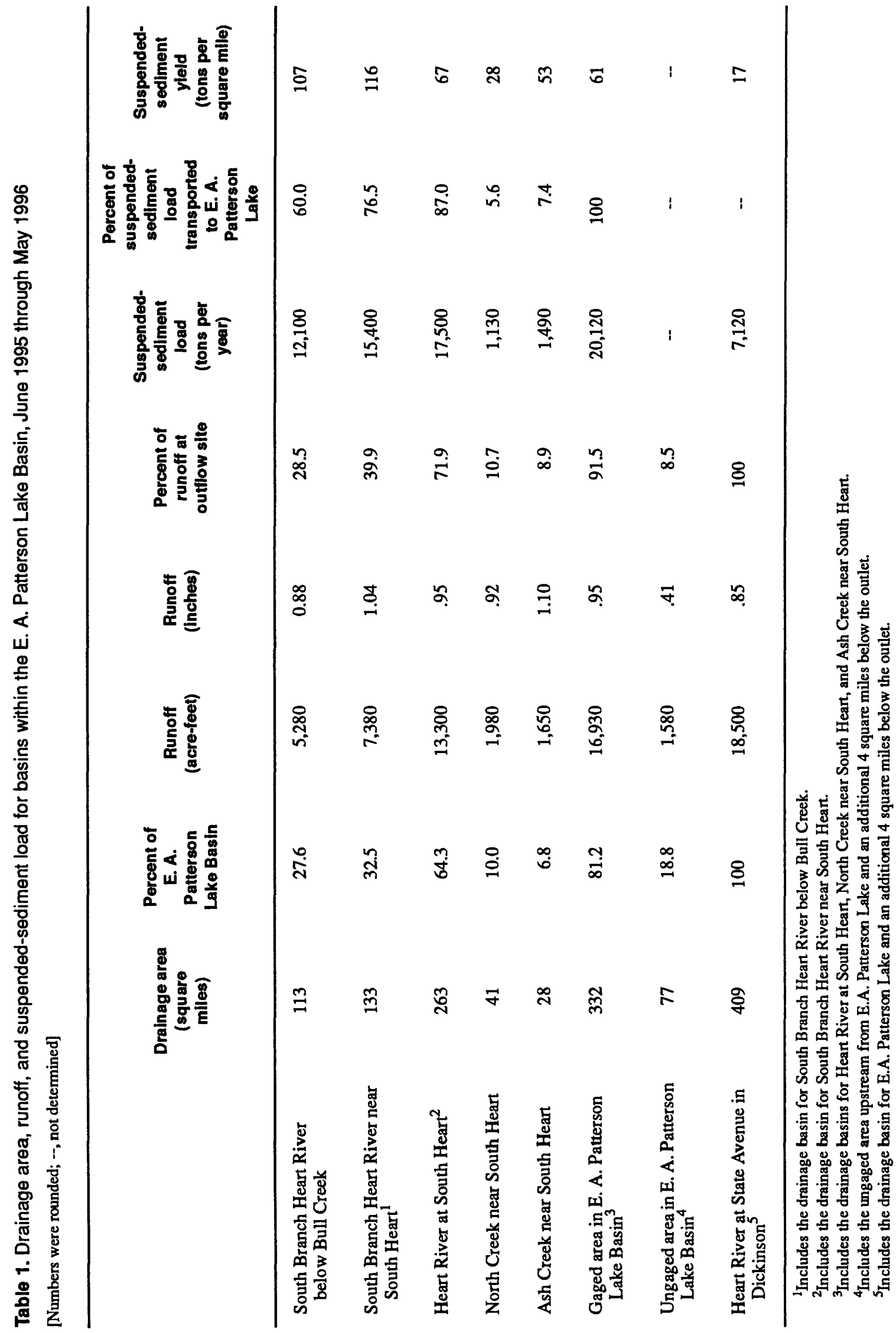


greater than the yield for the other gaged basins in the Patterson Lake Basin. The North Creek near South Heart Basin contributed 1,130 tons per year to the lake, and the Ash Creek near South Heart Basin contributed 1,490 tons per year. Together, these two basins contributed only 13 percent of the total suspended-sediment load entering the lake. The yield from these two basins was less than half of the yield from the South Branch Heart River near South Heart Basin.

Selected suspended-sediment samples were analyzed for particle-size distribution to determine the size of sediment entering Patterson Lake. In most of the samples collected from the tributary sites, more than 90 percent of the sediment was less than 0.062 millimeter in particle size (silt and clay) (table 2 ). It may take days to weeks for silt and clay to settle out of suspension; so, once a silt or clay particle becomes suspended it probably remains suspended until it reaches Patterson Lake. However, field observations indicated that after high flows receded, a thin layer of silt and clay was deposited in flooded parts of the river valleys. This thin layer of silt and clay indicates that not all of the material that was eroded and transported within the basin entered Patterson Lake.

Bed-sediment samples were collected on September 20,1995, from the tributary sites (table 3). In samples collected from South Branch Heart River below Bull Creek and South Branch Heart River near South Heart, between about 75 and 78 percent of the sediment was less than 0.062 millimeter in particle size (silt and clay). Most of the remaining sediment ranged from 0.062 to 0.500 millimeter in particle size (very fine to medium sand). The South Branch Heart River drains a badlands area that consists of claystones and interbedded siltstones and sandstones (Maderak, 1966). In samples collected from the Heart River at South Heart, North Creek near South Heart, and Ash Creek near South Heart, between about 9 and 27 percent of the sediment was less than 0.062 millimeter in particle size, and between about 44 and 47 percent was greater than 1.00 millimeter in particle size (very coarse sand or larger). The Heart River, North Creek, and Ash Creek drain areas that are mostly composed of sandstone deposits with some alternating beds of lignite and shale (Maderak, 1966).

The total nitrogen load entering Patterson Lake was 41.02 tons per year (table 4), and the total nitrogen yield for the Patterson Lake Basin was 0.124 ton per square mile. Of the 41.02 tons per year, the Heart River at South Heart Basin contributed 32.48 tons per year (79.2 percent). The South Branch Heart River below Bull Creek Basin and the North Creek near South Heart Basin had the smallest total nitrogen yields per basin, and the South Branch Heart River near South Heart Basin and the Ash Creek near South Heart Basin had the largest yields. The South Branch Heart River near South Heart Basin, not including the South Branch Heart River below Bull Creek Basin, had a yield of 0.359 ton per square mile, which is considerably larger than the yield from other basins.

The total phosphorus load entering Patterson Lake was 11.85 tons per year (table 4), and the total phosphorus yield for the Patterson Lake Basin was 0.036 ton per square mile. The pattern of phosphorus loading was similar to that of nitrogen. Of the 11.85 tons per year, the Heart River at South Heart Basin contributed 9.32 tons per year (78.6 percent). The South Branch Heart River below Bull Creek Basin and the North Creek near South Heart Basin had the smallest total phosphorus yields per basin, and the South Branch Heart River near South Heart Basin and the Ash Creek near South Heart Basin had the largest yields. The South Branch Heart River near South Heart Basin, not including the South Branch Heart River below Bull Creek Basin, had a yield of 0.209 ton per square mile, which is considerably larger than the yield from other basins.

\section{Loads Leaving and Remaining in Patterson Lake}

During the study period, the total suspended-sediment load entering Patterson Lake was 20,120 tons per year, and the total suspended-sediment load leaving the lake at the outflow site was 7,120 tons per year 
Table 2. Percent of suspended sediment less than 0.062 millimeter in particle size in selected samples collected from tributary and outflow sites, June 1995 through May 1996

\begin{tabular}{|c|c|c|c|}
\hline Site & Date & $\begin{array}{l}\text { Suspended-sediment } \\
\text { concentration } \\
\text { (milligrams per liter) }\end{array}$ & $\begin{array}{c}\text { Percent of } \\
\text { suspended } \\
\text { sediment less } \\
\text { than } 0.062 \text { millimeter }\end{array}$ \\
\hline \multirow[t]{5}{*}{ South Branch Heart River below Bull Creek } & August 24, 1995 & 4,070 & 100 \\
\hline & August 24,1995 & 2,270 & 99.9 \\
\hline & March 11, 1996 & 1,150 & 99.8 \\
\hline & March 12, 1996 & 136 & 99.8 \\
\hline & March 14, 1996 & 331 & 99.9 \\
\hline \multirow[t]{6}{*}{ South Branch Heart River near South Heart } & August 24, 1995 & 4,340 & 99.5 \\
\hline & August 24, 1995 & 4,880 & 99.8 \\
\hline & February 9, 1996 & 203 & 93.4 \\
\hline & March 11, 1996 & 378 & 98.6 \\
\hline & March 12, 1996 & 458 & 99.7 \\
\hline & March 14, 1996 & 601 & 90.1 \\
\hline \multirow[t]{8}{*}{ Heart River at South Heart } & August 24, 1995 & 2,340 & 99.4 \\
\hline & August 24, 1995 & 2,180 & 99.6 \\
\hline & September 20, 1995 & 112 & 96.0 \\
\hline & November 30, 1995 & 155 & 84.6 \\
\hline & February 9, 1996 & 143 & 97.7 \\
\hline & March 11, 1996 & 184 & 97.0 \\
\hline & March 12, 1996 & 477 & 98.5 \\
\hline & March 14, 1996 & 344 & 98.6 \\
\hline \multirow[t]{4}{*}{ North Creek near South Heart } & August 24, 1995 & 2,100 & 99.9 \\
\hline & August 25,1995 & 1,340 & 96.6 \\
\hline & March 11, 1996 & 74 & 83.3 \\
\hline & March 12, 1996 & 558 & 99.1 \\
\hline \multirow[t]{4}{*}{ Ash Creek near South Heart } & August 24, 1995 & 2,700 & 99.3 \\
\hline & August 25, 1995 & 4,120 & 99.3 \\
\hline & March 11, 1996 & 541 & 97.7 \\
\hline & March 11, 1996 & 324 & 98.6 \\
\hline \multirow[t]{2}{*}{ Heart River at State Avenue in Dickinson } & August 25, 1995 & 159 & 81.6 \\
\hline & April 15, 1996 & 94 & 35.4 \\
\hline
\end{tabular}


Table 3. Particle-size distribution in bed-sediment samples collected from tributary sites, September 20, 1995 $[-$, not determined $]$

\begin{tabular}{|c|c|c|c|c|c|}
\hline \multirow[b]{2}{*}{$\begin{array}{l}\text { Partlcle slze } \\
\text { (millimeters) }\end{array}$} & \multicolumn{5}{|c|}{$\begin{array}{l}\text { Partlcle-size distribution } \\
\text { (percent) }\end{array}$} \\
\hline & $\begin{array}{l}\text { South Branch } \\
\text { Heart Rlver } \\
\text { below Bull Creek }\end{array}$ & $\begin{array}{l}\text { South Branch } \\
\text { Heart RIver near } \\
\text { South Heart }\end{array}$ & $\begin{array}{l}\text { Heart River at } \\
\text { South Heart }\end{array}$ & $\begin{array}{c}\text { North Creek } \\
\text { near South Heart }\end{array}$ & $\begin{array}{l}\text { Ash Creek near } \\
\text { South Heart }\end{array}$ \\
\hline $\begin{array}{l}\text { Less than } 0.062 \\
\text { (silt and clay) }\end{array}$ & 77.9 & 75.1 & 21.2 & 26.8 & 9.4 \\
\hline $\begin{array}{l}0.062 \text { to } 0.125 \\
\text { (very fine sand) }\end{array}$ & 8.2 & 13.6 & 3.8 & 6.9 & .9 \\
\hline $\begin{array}{l}0.125 \text { to } 0.250 \\
\text { (fine sand) }\end{array}$ & 4.6 & 9.0 & 12.6 & 12.6 & 2.5 \\
\hline $\begin{array}{l}0.250 \text { to } 0.500 \\
\text { (medium sand) }\end{array}$ & 3.6 & 2.3 & 12.9 & 7.2 & 33.5 \\
\hline $\begin{array}{l}0.500 \text { to } 1.00 \\
\text { (coarse sand) }\end{array}$ & 2.7 & -- & 2.3 & 2.2 & 8.9 \\
\hline $\begin{array}{l}\text { Greater than } 1.00 \\
\text { (very coarse sand } \\
\text { or larger) }\end{array}$ & 3.0 & -- & 47.2 & 44.3 & 44.8 \\
\hline
\end{tabular}

(table 1). The suspended-sediment load remaining in the lake was 13,000 tons per year, which is the difference between the load entering the lake and the load leaving the lake. Patterson Lake had a sediment-trap efficiency of 65 percent, which means the reservoir retained 65 percent of the suspendedsediment load entering the lake.

The total nitrogen load entering Patterson Lake was 41.02 tons per year, and the total nitrogen load leaving the lake at the outflow site was 39.46 tons per year (table 4). The nitrogen load remaining in the lake was 1.56 tons per year ( 4 percent), which is the difference between the load entering the lake and the load leaving the lake.

The total phosphorus load entering Patterson Lake was 11.85 tons per year, and the total phosphorus load leaving the lake at the outflow site was 5.57 tons per year (table 4). The phosphorus load remaining in the lake was 6.28 tons per year ( 53 percent), which is the difference between the load entering the lake and the load leaving the lake.

Patterson Lake is a "sink" for sediment, total nitrogen, and total phosphorus. This means that the mass of these constituents entering the lake is greater than the mass leaving the lake. Depending on lake conditions, a part of the sediment entering the lake settles to the lake bottom because of its weight. If conditions in the lake are turbid, some sediment particles remain in suspension and can be carried over the spillway and downstream. In Patterson Lake, only 65 percent of the incoming suspended-sediment load settled to the lake bottom, possibly because most of the load entering the lake is composed of silt and clay particles. These particles are lightweight and may require days to settle to the lake bottom, particularly if 


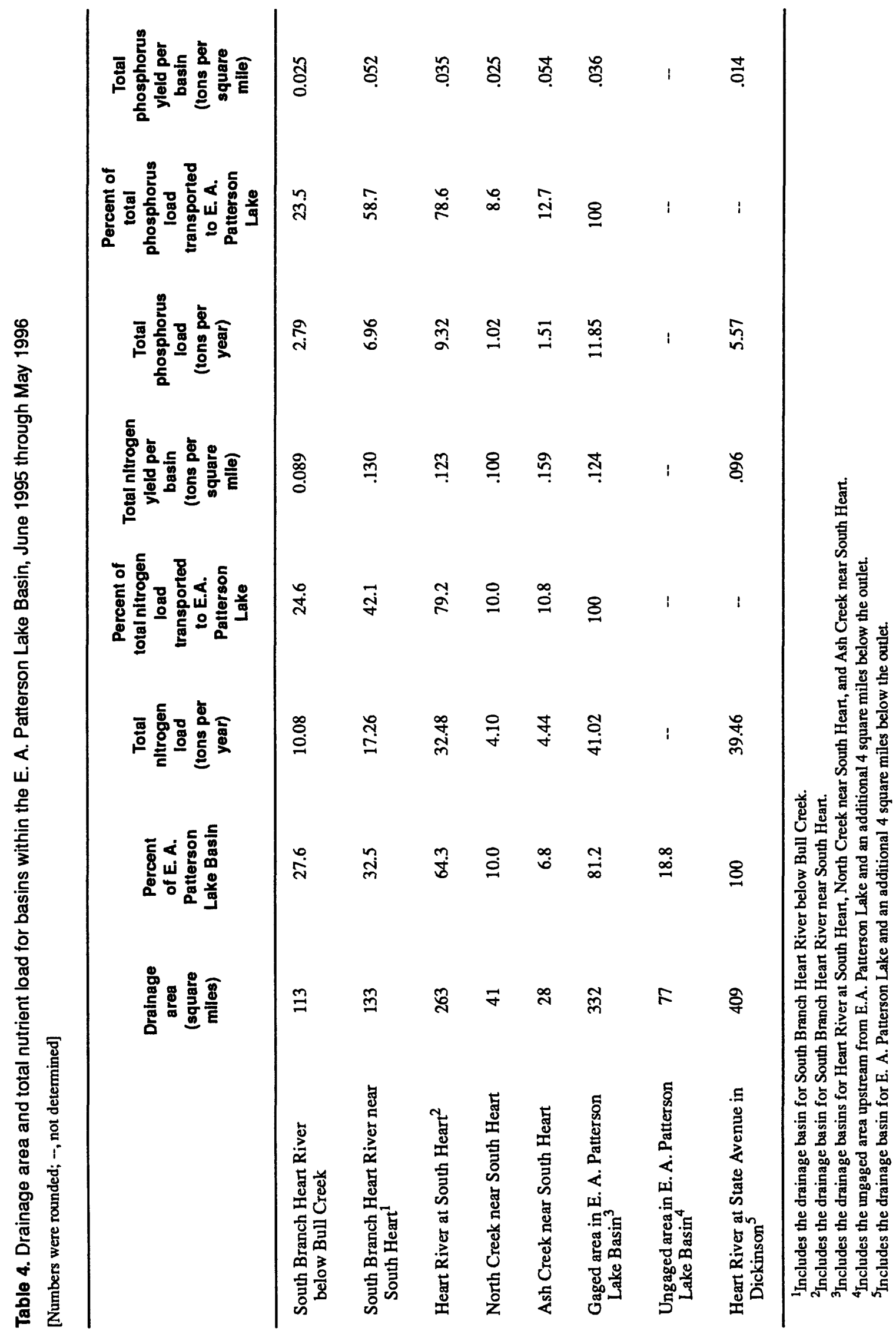


the lake is agitated by wind movement such as often happens at Patterson Lake. Generally, most reservoirs retain a larger percentage of the incoming load than that retained in Patterson Lake (W.R. Berkas, U.S. Geological Survey, oral commun., 1996).

Because of the sediment conditions occurring in Patterson Lake, nearly all of the sediment leaving the lake would be expected to be less than 0.062 millimeter in particle size. However, analyses of suspendedsediment samples collected from the outflow site, Heart River at State Avenue in Dickinson, indicate that about 35 to 82 percent of the sediment is less than 0.062 millimeter in particle size (table 2). The occurrence of sands in the suspended-sediment distribution possibly indicates that sand particles are being introduced into the river from the 4-square mile area that includes the channel between Patterson Lake Dam and State Avenue. Because these sands contribute to the suspended-sediment load downstream from the dam, the sediment-trap efficiency of Patterson Lake could be greater than 65 percent.

The accumulation of nutrients in Patterson Lake is typical of lakes where extemal loading exceeds the lake's ability to assimilate nutrients through natural biological and chemical processes. Total nutrients are dissolved nutrients and nutrients in particulate form. Dissolved nutrients are used by plant material, such as algae. When the plant material dies, it settles to the lake bottom, decomposes, and releases ammonia that is oxidized into nitrites and then nitrates. Nutrients in particulate form settle to the lake bottom.

Bed-sediment samples were collected on July 20,1995, from the lake sites (table 5). In samples collected from sites 1 and 2, 99.6 percent of the sediment was less than 0.062 millimeter in particle size. Site 1, which is the deepest of the three sites, is located closest to the reservoir's spillway; and site 3, which is the shallowest of the three sites, is located closest to the inflow from the Heart River. The particle-size distribution at site 3 was different from that at sites 1 and 2 . In samples collected from site 3 , only 35.9 percent of the sediment was less than 0.062 millimeter in particle size. This percentage was much smaller than at sites 1 and 2. Most of the sediment at site 3 ranged from 0.062 to 0.500 millimeter in particle size. The larger particles at site 3 are typical of sites located closest to where streams enter a lake. The change in water velocity as water enters the lake causes larger, heavier particles to settle to the lake bottom first. The smaller, lighter particles are carried farther into the lake and usually are deposited close to the dam as the velocity of water moving through the lake declines.

\section{WATER-QUALITY VARIATIONS IN PATTERSON LAKE}

Specific conductance is an indicator of the dissolved-solids concentration in water. Generally, the larger the specific-conductance value, the larger the dissolved-solids concentration. During the study period, specific-conductance values ranged from 559 to 1,150 microsiemens per centimeter at 25 degrees Celsius and varied little among sites (table 6). Specific-conductance values decreased substantially from August to September 1995. The decrease indicated dilution of the lake from runoff caused by greaterthan-normal precipitation at the end of August. Antecedent conditions prior to August that possibly influenced the amount of runoff into the lake were the greater-than-normal precipitation from May to August, preexisting soil conditions, and the slow down in vegetative growth.

$\mathrm{pH}$ is a measure of the effective hydrogen-ion concentration in water or the acidity or alkalinity of the water. During the study period, $\mathrm{pH}$ values ranged from 6.7 to 8.4 and varied little among sites (table 6). $\mathrm{pH}$ values were smaller during the spring and slightly larger during the summer months. The largest $\mathrm{pH}$ values occurred during July 1995.

Water temperatures reflected strong seasonal variability during the study period (table 6). The temperatures ranged from 4.0 degrees Celsius during October and November 1995 to 22.5 degrees Celsius 
Table 5. Particle size distribution in bed-sediment samples collected from lake sites, July 20, 1995

$[-$, not determined $]$

\begin{tabular}{|c|c|c|c|}
\hline \multirow[b]{2}{*}{$\begin{array}{l}\text { Particle size } \\
\text { (millimeters) }\end{array}$} & \multicolumn{3}{|c|}{$\begin{array}{l}\text { Particle-size distribution } \\
\text { (percent) }\end{array}$} \\
\hline & Site 1 & Site 2 & Site 3 \\
\hline $\begin{array}{l}\text { Less than } 0.062 \\
\text { (silt and clay) }\end{array}$ & 99.6 & 99.6 & 35.9 \\
\hline $\begin{array}{l}0.062 \text { to } 0.125 \\
\text { (very fine sand) }\end{array}$ & .3 & .3 & 9.2 \\
\hline $\begin{array}{l}0.125 \text { to } 0.250 \\
\text { (fine sand) }\end{array}$ & .1 & .1 & 50.0 \\
\hline $\begin{array}{l}0.250 \text { to } 0.500 \\
\text { (medium sand) }\end{array}$ & -- & -- & 4.9 \\
\hline $\begin{array}{l}0.500 \text { to } 1.00 \\
\text { (coarse sand) }\end{array}$ & -- & -- & - \\
\hline $\begin{array}{l}\text { Greater than } 1.00 \\
\text { (very coarse sand or larger) }\end{array}$ & -- & -- & -- \\
\hline
\end{tabular}

during July 1995 and varied little among sites. The largest variation occurred at site 1 (the deepest lake site) during June 1995, indicating that the lake was stratified with regard to temperature.

Dissolved-oxygen concentrations in lakes are important because oxygen is needed by fish and other aquatic life. Generally, game fish need 5 milligrams per liter or more of dissolved oxygen to survive. At sites 1 and 2, dissolved-oxygen concentrations near the lake bottom were less than 5 milligrams per liter during June and July and greater than or equal to 5 milligrams per liter during the remainder of the year. At site 3, dissolved-oxygen concentrations were greater than 5 milligrams per liter during the entire year.

Generally, Secchi-disk transparency is measured to estimate light-extinction depths and to provide a measure of trophic state variations in lake environments (Carlson, 1977). During the study period, Secchidisk transparency in Patterson Lake ranged from 1.2 to 27 inches and varied little among sites (table 6). The smallest values occurred during June and July 1995, which was when biomass material and sediment were visually observed in the lake. The small values coincided with warmer water temperatures and longer periods of sunlight, which are needed for algae production. The largest values occurred during August 1995.

Nitrogen and phosphorus are essential for plant growth, especially for free-floating aquatic plant material such as algae. Therefore, the production rate of aquatic plant material may be large in water bodies that are enriched with those nutrients. Unfavorably large production rates of algae probably occur when nutrient supplies are at a maximum. If a nutrient supply is not at a maximum, the limited availability of that nutrient will limit plant growth and the nutrient is considered to be the limiting nutrient. Generally, phosphorus is the limiting nutrient in freshwater systems, and its availability probably is a critical factor in eutrophication of water bodies. Lakes and reservoirs in which total phosphorus concentrations are larger than 0.025 milligram per liter as P generally exhibit accelerated eutrophication (U.S. Environmental Protection Agency, 1986). 
Table 6. Depth profiles of physical properties at lake sites, June 1995 through May 1996

[ 1 meter equals 3.25 feet; $\mu \mathrm{S} / \mathrm{cm}$, microsiemens per centimeter at 25 degrees Celsius; ${ }^{\circ} \mathrm{C}$, degrees Celsius; $\mathrm{mg} / \mathrm{L}$, milligrams per liter, mm of $\mathrm{Hg}$. millimeters of mercury; mi/hr, miles per hour, --, not determined; <, less than]

\begin{tabular}{|c|c|c|c|c|c|c|c|c|}
\hline Date & $\begin{array}{c}\text { Depth } \\
\text { (meters) }\end{array}$ & $\begin{array}{c}\text { Specific } \\
\text { conductance } \\
(\mu \mathrm{S} / \mathrm{cm})\end{array}$ & $\begin{array}{c}\mathrm{pH} \\
\text { (standard } \\
\text { units) }\end{array}$ & $\begin{array}{l}\text { Water } \\
\text { temper. } \\
\text { ature } \\
\left({ }^{\circ} \mathrm{C}\right)\end{array}$ & $\begin{array}{l}\text { Dis- } \\
\text { solved } \\
\text { oxygen } \\
\text { (mg/L) }\end{array}$ & $\begin{array}{l}\text { Barometric } \\
\text { pressure } \\
(\mathrm{mm} \text { of } \mathrm{Hg})\end{array}$ & $\begin{array}{l}\text { Secchi- } \\
\text { disk } \\
\text { trans- } \\
\text { parency } \\
\text { (inches) }\end{array}$ & $\begin{array}{l}\text { Wind- } \\
\text { speed } \\
(\mathrm{mi} / \mathrm{hr})\end{array}$ \\
\hline \multicolumn{9}{|c|}{ Site 1} \\
\hline June 21, 1995 & $\begin{array}{r}0 \\
14.5 \\
25.5 \\
7.8\end{array}$ & $\begin{array}{l}1,040 \\
1,040 \\
1,020 \\
1,010\end{array}$ & $\begin{array}{l}8.0 \\
8.0 \\
7.6 \\
7.4\end{array}$ & $\begin{array}{l}21.5 \\
20.5 \\
17.5 \\
14.0\end{array}$ & $\begin{array}{r}8.7 \\
6.0 \\
2.6 \\
.4\end{array}$ & $\begin{array}{c}695 \\
-- \\
-- \\
--\end{array}$ & $\begin{array}{l}2.0 \\
-- \\
-- \\
--\end{array}$ & $\begin{array}{l}8.0 \\
- \\
-- \\
--\end{array}$ \\
\hline July 20,1995 & $\begin{array}{c}0 \\
14.0 \\
7.9\end{array}$ & $\begin{array}{l}1,060 \\
1,060 \\
1,060\end{array}$ & $\begin{array}{l}8.4 \\
7.6 \\
8.1\end{array}$ & $\begin{array}{l}22.5 \\
20.5 \\
18.0\end{array}$ & $\begin{array}{r}7.4 \\
3.3 \\
.1\end{array}$ & $\begin{array}{c}697 \\
-- \\
--\end{array}$ & $\begin{array}{l}3.6 \\
-- \\
--\end{array}$ & $\begin{array}{c}<5.0 \\
-- \\
--\end{array}$ \\
\hline August 22, 1995 & $\begin{array}{l}0 \\
6.7\end{array}$ & $\begin{array}{l}1,140 \\
1,140\end{array}$ & $\begin{array}{l}8.2 \\
8.1\end{array}$ & $\begin{array}{l}21.0 \\
20.0\end{array}$ & $\begin{array}{l}8.0 \\
6.7\end{array}$ & $\begin{array}{c}697 \\
--\end{array}$ & 27.0 & $\begin{array}{l}0 \\
--\end{array}$ \\
\hline September 18,1995 & $\begin{array}{l}0 \\
7.6\end{array}$ & $\begin{array}{l}578 \\
575\end{array}$ & $\begin{array}{l}7.5 \\
7.5\end{array}$ & $\begin{array}{l}17.0 \\
16.5\end{array}$ & $\begin{array}{l}5.5 \\
5.4\end{array}$ & $\begin{array}{c}698 \\
--\end{array}$ & $\begin{array}{l}6.0 \\
--\end{array}$ & $\begin{array}{c}<5.0 \\
-\end{array}$ \\
\hline October 11, 1995 & $\begin{array}{l}0 \\
6.1\end{array}$ & $\begin{array}{l}575 \\
593\end{array}$ & $\begin{array}{l}7.6 \\
8.0\end{array}$ & $\begin{array}{r}11.0 \\
4.0\end{array}$ & $\begin{array}{l}10.0 \\
10.0\end{array}$ & $\begin{array}{c}694 \\
--\end{array}$ & $\begin{array}{l}7.0 \\
--\end{array}$ & $\begin{array}{c}<.0 \\
-\end{array}$ \\
\hline November 1, 1995 & $\begin{array}{l}0 \\
4.0\end{array}$ & $\begin{array}{l}594 \\
593\end{array}$ & $\begin{array}{l}7.8 \\
8.0\end{array}$ & $\begin{array}{l}4.0 \\
4.0\end{array}$ & $\begin{array}{l}10.3 \\
10.0\end{array}$ & $\begin{array}{c}699 \\
--\end{array}$ & $\begin{array}{l}9.0 \\
--\end{array}$ & $\begin{array}{l}8.0 \\
-\end{array}$ \\
\hline May 7, 1996 & $\begin{array}{l}0 \\
7.5\end{array}$ & $\begin{array}{l}563 \\
569\end{array}$ & $\begin{array}{l}7.0 \\
7.3\end{array}$ & $\begin{array}{l}8.0 \\
8.0\end{array}$ & $\begin{array}{l}9.0 \\
5.0\end{array}$ & 693 & $\begin{array}{l}6.0 \\
--\end{array}$ & $<5.0$ \\
\hline \multicolumn{9}{|c|}{ Site 2} \\
\hline July 20,1995 & $\begin{array}{c}0 \\
14.5 \\
6.5\end{array}$ & $\begin{array}{l}1,060 \\
1,060 \\
1,050\end{array}$ & $\begin{array}{l}8.4 \\
7.9 \\
7.7\end{array}$ & $\begin{array}{l}22.5 \\
21.0 \\
19.5\end{array}$ & $\begin{array}{l}7.7 \\
1.7 \\
1.0\end{array}$ & $\begin{array}{c}697 \\
-- \\
--\end{array}$ & $\begin{array}{l}4.2 \\
-- \\
--\end{array}$ & $\begin{array}{c}<.0 \\
- \\
--\end{array}$ \\
\hline \multicolumn{9}{|c|}{ Site 3} \\
\hline June 21, 1995 & $\begin{array}{l}0 \\
4.0\end{array}$ & $\begin{array}{l}1,050 \\
1,050\end{array}$ & $\begin{array}{l}7.8 \\
8.0\end{array}$ & $\begin{array}{l}21.5 \\
21.5\end{array}$ & $\begin{array}{l}8.0 \\
7.0\end{array}$ & $\begin{array}{c}696 \\
--\end{array}$ & $\begin{array}{l}1.2 \\
--\end{array}$ & $\begin{array}{c}12.0 \\
--\end{array}$ \\
\hline July 20, 1995 & $\begin{array}{l}0 \\
3.6\end{array}$ & $\begin{array}{l}1,060 \\
1,070\end{array}$ & $\begin{array}{l}8.4 \\
8.4\end{array}$ & $\begin{array}{l}22.5 \\
22.5\end{array}$ & $\begin{array}{l}7.7 \\
7.2\end{array}$ & 696 & $\begin{array}{l}1.9 \\
--\end{array}$ & $<-5.0$ \\
\hline August 22, 1995 & $\begin{array}{l}0 \\
3.4\end{array}$ & $\begin{array}{l}1,150 \\
1,150\end{array}$ & $\begin{array}{l}8.3 \\
8.2\end{array}$ & $\begin{array}{l}21.5 \\
20.5\end{array}$ & $\begin{array}{l}8.0 \\
6.6\end{array}$ & $\begin{array}{c}697 \\
--\end{array}$ & $\begin{array}{c}17.0 \\
--\end{array}$ & $\begin{array}{c}<.0 \\
--\end{array}$ \\
\hline September 18,1995 & $\begin{array}{l}0 \\
4.0\end{array}$ & $\begin{array}{l}566 \\
560\end{array}$ & $\begin{array}{l}7.4 \\
7.5\end{array}$ & $\begin{array}{l}17.0 \\
16.5\end{array}$ & $\begin{array}{l}6.1 \\
5.8\end{array}$ & $\begin{array}{c}697 \\
--\end{array}$ & $\begin{array}{l}6.0 \\
--\end{array}$ & $\begin{array}{c}<5.0 \\
--\end{array}$ \\
\hline October 11, 1995 & $\begin{array}{l}0 \\
3.7\end{array}$ & $\begin{array}{l}578 \\
579\end{array}$ & $\begin{array}{l}7.5 \\
7.7\end{array}$ & $\begin{array}{l}10.5 \\
10.5\end{array}$ & $\begin{array}{l}8.8 \\
8.7\end{array}$ & $\begin{array}{c}694 \\
--\end{array}$ & $\begin{array}{l}7.0 \\
--\end{array}$ & $\begin{array}{c}<.0 \\
--\end{array}$ \\
\hline November 1, 1995 & $\begin{array}{l}0 \\
6.2\end{array}$ & $\begin{array}{l}587 \\
584\end{array}$ & $\begin{array}{l}7.9 \\
8.0\end{array}$ & $\begin{array}{l}5.0 \\
4.5\end{array}$ & $\begin{array}{l}9.9 \\
9.7\end{array}$ & $\begin{array}{c}699 \\
--\end{array}$ & $\begin{array}{c}10.0 \\
--\end{array}$ & $\begin{array}{c}10.0 \\
--\end{array}$ \\
\hline May 7, 1996 & $\begin{array}{l}0 \\
3.6\end{array}$ & $\begin{array}{l}559 \\
560\end{array}$ & $\begin{array}{l}6.7 \\
7.2\end{array}$ & $\begin{array}{l}8.0 \\
8.0\end{array}$ & $\begin{array}{l}9.4 \\
8.7\end{array}$ & $\begin{array}{c}693 \\
--\end{array}$ & $\begin{array}{l}6.0 \\
--\end{array}$ & $\begin{array}{c}<5.0 \\
--\end{array}$ \\
\hline
\end{tabular}

${ }^{1}$ Values for top of thermocline.

${ }^{2}$ Values for bottom of thermocline. 
Concentrations of selected water-quality constituents in samples collected from sites located on Patterson Lake are given in table 7. The concentrations are within normal ranges for surface water in that area of the State (North Dakota State Department of Health and Consolidated Laboratories, 1991; U.S. Geological Survey, 1993).

Organic nitrogen is the nitrogen present in organic material and is related to the algae biomass in surface waters. During the study period, organic nitrogen was the dominant nitrogen in Patterson Lake. Concentrations ranged from 0.57 to 1.2 milligrams per liter as $\mathrm{N}$ (table 7) and generally were smaller during September, October, and November when algae begin to die off and larger during June, July, and August when the algae population is large. When organic nitrogen concentrations are large, such as during June, July, and August, total nitrite plus nitrate and total ammonia concentrations generally are small because nitrite, nitrate, and ammonia are the forms of nitrogen that can be used by algae. Thus, when algae production is large, nitrite, nitrate, and ammonia concentrations decrease. During the fall, the algae die, settle to the lake bottom, and decompose to nitrite, nitrate, and ammonia, and the concentrations of these forms of nitrogen increase.

During the study period, total phosphorus concentrations ranged from 0.101 to 0.227 milligram per liter as $\mathrm{P}$ in Patterson Lake and varied little among sites (table 7). All phosphorus concentrations were greater than 0.025 milligram per liter as $P$, indicating that accelerated eutrophication could occur (U.S. Environmental Protection Agency, 1986).

Generally, plants have a nitrogen:phosphorus ratio of 7:1 (Wetzel, 1983), which means an environment of 7 parts nitrogen and 1 part phosphorus will produce a healthy plant. In Patterson Lake, the ratio of nitrogen (nitrite, nitrate, and ammonia) available for plant uptake to phosphorus generally is less than 7 to 1. When the ratio is less than 7 to 1 , nitrite plus nitrate and ammonia concentrations may limit the growth of algae that do not fix nitrogen from the atmosphere. However, most algae in Patterson Lake are able to fix nitrogen and, thus, are not limited by the lower nitrogen concentrations in the lake.

Chlorophyll $a$ is an indicator of plankton, such as algae, that are capable of photosynthesis. During the study period, chlorophyll $a$ concentrations ranged from less than 3.0 to 68 micrograms per liter and varied little among sites (table 7). The concentrations generally were larger during July and August. The large concentrations are consistent with unsightly algal blooms in the lake and coincided with warmer water temperatures and longer periods of sunlight. During 1994, Devils Lake, a hypereutrophic lake in northeastern North Dakota, had chlorophyll $a$ concentrations that ranged from less than 3.0 to 43 micrograms per liter (Harkness and others, 1995). The large concentrations in Patterson Lake also indicate hypereutrophic conditions and that, at times, algae production can be large.

\section{POTENTIAL FOR RELEASES FROM LAKE SEDIMENTS}

Bed-sediment samples collected from the lake sites on July 20,1995, were combined with lake water, shaken, and analyzed for chemical composition. The analyses were performed at the NDDH laboratory. Concentrations of selected water-quality constituents in the elutriate sample then were compared to concentrations in the bottom-water sample collected from each site (table 8).

The concentrations of ions in the elutriate samples generally showed few systematic differences from the concentrations in the bottom-water samples. The major-ion concentrations in the elutriate samples were larger at two sites and smaller at one site except for sulfate, which had larger concentrations at all three sites. Alkalinity concentrations were larger at sites 1 and 2. Iron concentrations in the elutriate samples were smaller at all three sites, and manganese concentrations were larger at all three sites. 
Table 7. Concentrations of selected water-quality constituents in samples collected from lake sites, June 1995 through May 1996

[Water-quality analyses by the North Dakota Department of Health; $\mathrm{m}$, meters; 1 meter equals $3.25 \mathrm{feet;} \mathrm{mg} / \mathrm{L}$, milligrams per liter, $\mu \mathrm{g} / \mathrm{L}$, micrograms per liter, --, not determined; $<$, less than]

\begin{tabular}{|c|c|c|c|c|c|c|c|c|c|}
\hline Date & $\begin{array}{c}\text { Depth } \\
\text { (m) }\end{array}$ & $\begin{array}{c}\text { Alka- } \\
\text { linity, } \\
\text { total } \\
(\mathrm{mg} / \mathrm{L} \text { as } \\
\left.\mathrm{CaCO}_{3}\right)\end{array}$ & $\begin{array}{c}\text { Calclum, } \\
\text { total } \\
\text { (mg/L } \\
\text { as Ca) }\end{array}$ & $\begin{array}{l}\text { Magne- } \\
\text { sium, } \\
\text { total } \\
\text { (mg/L } \\
\text { as Mg) }\end{array}$ & $\begin{array}{c}\text { Sodium, } \\
\text { total } \\
\text { (mg/L } \\
\text { as } \mathrm{Na} \text { ) }\end{array}$ & $\begin{array}{l}\text { Potas- } \\
\text { sium, } \\
\text { total } \\
\text { (mg/L } \\
\text { as K) }\end{array}$ & $\begin{array}{l}\text { Iron, } \\
\text { total } \\
(\mu \mathrm{g} / \mathrm{L} \\
\text { as Fe) }\end{array}$ & $\begin{array}{c}\text { Manga- } \\
\text { nese } \\
\text { total } \\
(\mu g / L \\
\text { as Mn) }\end{array}$ & $\begin{array}{c}\text { Sulfate, } \\
\text { total } \\
\text { (mg/L } \\
\left.\text { as } \mathrm{SO}_{4}\right)\end{array}$ \\
\hline \multicolumn{10}{|c|}{ Site 1} \\
\hline June 21,1995 & $\begin{array}{c}0 \\
14.5 \\
25.5 \\
7.8\end{array}$ & $\begin{array}{l}210 \\
211 \\
210 \\
214\end{array}$ & $\begin{array}{l}39 \\
36 \\
38 \\
38\end{array}$ & $\begin{array}{l}20 \\
19 \\
20 \\
19\end{array}$ & $\begin{array}{l}150 \\
140 \\
150 \\
150\end{array}$ & $\begin{array}{l}8.6 \\
8.7 \\
9.0 \\
9.4\end{array}$ & $\begin{array}{r}730 \\
750 \\
790 \\
1,000\end{array}$ & $\begin{array}{r}74 \\
100 \\
160 \\
810\end{array}$ & $\begin{array}{l}240 \\
230 \\
310 \\
300\end{array}$ \\
\hline July 20,1995 & $\begin{array}{r}0 \\
1 \\
14.0 \\
7.9\end{array}$ & $\begin{array}{l}220 \\
218 \\
222\end{array}$ & $\begin{array}{l}42 \\
43 \\
39\end{array}$ & $\begin{array}{l}22 \\
23 \\
20\end{array}$ & $\begin{array}{l}170 \\
180 \\
150\end{array}$ & $\begin{array}{l}11 \\
11 \\
9.1\end{array}$ & $\begin{array}{l}270 \\
340 \\
510\end{array}$ & $\begin{array}{r}64 \\
72 \\
460\end{array}$ & $\begin{array}{l}320 \\
330 \\
310\end{array}$ \\
\hline August 22, 1995 & $\begin{array}{l}0 \\
6.7\end{array}$ & $\begin{array}{l}247 \\
247\end{array}$ & $\begin{array}{l}47 \\
46\end{array}$ & $\begin{array}{l}24 \\
24\end{array}$ & $\begin{array}{l}200 \\
190\end{array}$ & $\begin{array}{l}12 \\
11\end{array}$ & $\begin{array}{l}230 \\
250\end{array}$ & $\begin{array}{l}140 \\
160\end{array}$ & $\begin{array}{l}320 \\
300\end{array}$ \\
\hline September 18, 1995 & $\begin{array}{l}0 \\
7.6\end{array}$ & $\begin{array}{l}141 \\
132\end{array}$ & $\begin{array}{l}30 \\
28\end{array}$ & $\begin{array}{l}12 \\
12\end{array}$ & $\begin{array}{l}81 \\
71\end{array}$ & $\begin{array}{l}9.8 \\
9.0\end{array}$ & $\begin{array}{l}2,200 \\
2,900\end{array}$ & $\begin{array}{l}150 \\
190\end{array}$ & $\begin{array}{l}150 \\
160\end{array}$ \\
\hline October 11,1995 & $\begin{array}{l}0 \\
6.1\end{array}$ & $\begin{array}{l}131 \\
135\end{array}$ & $\begin{array}{l}26 \\
31\end{array}$ & $\begin{array}{l}12 \\
13\end{array}$ & $\begin{array}{l}61 \\
78\end{array}$ & $\begin{array}{c}7.9 \\
10\end{array}$ & $\begin{array}{l}3,300 \\
3,400\end{array}$ & $\begin{array}{l}100 \\
100\end{array}$ & $\begin{array}{l}140 \\
140\end{array}$ \\
\hline November 1,1995 & $\begin{array}{l}0 \\
4.0\end{array}$ & $\begin{array}{l}145 \\
151\end{array}$ & $\begin{array}{l}32 \\
32\end{array}$ & $\begin{array}{l}13 \\
13\end{array}$ & $\begin{array}{l}76 \\
72\end{array}$ & $\begin{array}{l}9.1 \\
8.6\end{array}$ & $\begin{array}{l}3,000 \\
2,500\end{array}$ & $\begin{array}{l}71 \\
64\end{array}$ & $\begin{array}{l}170 \\
170\end{array}$ \\
\hline May 7, 1996 & $\begin{array}{l}0 \\
7.5\end{array}$ & $\begin{array}{l}111 \\
112\end{array}$ & $\begin{array}{l}25 \\
22\end{array}$ & $\begin{array}{l}13 \\
12\end{array}$ & $\begin{array}{l}76 \\
65\end{array}$ & $\begin{array}{l}9.2 \\
8.6\end{array}$ & $\begin{array}{l}3,100 \\
4,900\end{array}$ & $\begin{array}{l}120 \\
260\end{array}$ & $\begin{array}{l}160 \\
160\end{array}$ \\
\hline \multicolumn{10}{|c|}{ Site 2} \\
\hline July 20, 1995 & $\begin{array}{c}0 \\
14.5 \\
6.5\end{array}$ & $\begin{array}{l}219 \\
222 \\
222\end{array}$ & $\begin{array}{l}43 \\
35 \\
44\end{array}$ & $\begin{array}{l}23 \\
18 \\
23\end{array}$ & $\begin{array}{l}170 \\
140 \\
180\end{array}$ & $\begin{array}{c}11 \\
9.2 \\
11\end{array}$ & $\begin{array}{l}250 \\
270 \\
520\end{array}$ & $\begin{array}{r}68 \\
79 \\
160\end{array}$ & $\begin{array}{l}320 \\
270 \\
310\end{array}$ \\
\hline \multicolumn{10}{|c|}{ Site 3} \\
\hline June 21, 1995 & $\begin{array}{l}0 \\
4.0\end{array}$ & $\begin{array}{l}212 \\
211\end{array}$ & $\begin{array}{l}37 \\
40\end{array}$ & $\begin{array}{l}20 \\
21\end{array}$ & $\begin{array}{l}150 \\
150\end{array}$ & $\begin{array}{l}8.9 \\
9.2\end{array}$ & $\begin{array}{r}1,100 \\
660\end{array}$ & $\begin{array}{l}130 \\
150\end{array}$ & $\begin{array}{l}220 \\
330\end{array}$ \\
\hline July 20, 1995 & $\begin{array}{l}0 \\
3.6\end{array}$ & $\begin{array}{l}222 \\
223\end{array}$ & $\begin{array}{l}35 \\
33\end{array}$ & $\begin{array}{l}18 \\
17\end{array}$ & $\begin{array}{l}140 \\
140\end{array}$ & $\begin{array}{l}8.3 \\
8.4\end{array}$ & $\begin{array}{l}540 \\
650\end{array}$ & $\begin{array}{l}120 \\
110\end{array}$ & $\begin{array}{l}310 \\
270\end{array}$ \\
\hline August 22, 1995 & $\begin{array}{l}0 \\
3.4\end{array}$ & $\begin{array}{l}248 \\
248\end{array}$ & $\begin{array}{l}46 \\
42\end{array}$ & $\begin{array}{l}23 \\
22\end{array}$ & $\begin{array}{l}200 \\
170\end{array}$ & $\begin{array}{c}12 \\
9.8\end{array}$ & $\begin{array}{l}300 \\
420\end{array}$ & $\begin{array}{l}130 \\
150\end{array}$ & $\begin{array}{l}290 \\
380\end{array}$ \\
\hline September 18,1995 & $\begin{array}{l}0 \\
4.0\end{array}$ & $\begin{array}{l}126 \\
129\end{array}$ & $\begin{array}{l}27 \\
27\end{array}$ & $\begin{array}{l}12 \\
11\end{array}$ & $\begin{array}{l}68 \\
66\end{array}$ & $\begin{array}{l}8.3 \\
8.3\end{array}$ & $\begin{array}{l}2,700 \\
2,500\end{array}$ & $\begin{array}{l}150 \\
140\end{array}$ & $\begin{array}{l}150 \\
150\end{array}$ \\
\hline October 11,1995 & $\begin{array}{l}0 \\
3.7\end{array}$ & $\begin{array}{l}141 \\
139\end{array}$ & $\begin{array}{l}28 \\
29\end{array}$ & $\begin{array}{l}12 \\
12\end{array}$ & $\begin{array}{l}66 \\
67\end{array}$ & $\begin{array}{l}9.0 \\
8.9\end{array}$ & $\begin{array}{l}4,400 \\
4,500\end{array}$ & $\begin{array}{l}110 \\
120\end{array}$ & $\begin{array}{l}140 \\
140\end{array}$ \\
\hline November 1, 1995 & $\begin{array}{l}0 \\
6.2\end{array}$ & $\begin{array}{l}144 \\
141\end{array}$ & $\begin{array}{l}31 \\
31\end{array}$ & $\begin{array}{l}13 \\
13\end{array}$ & $\begin{array}{l}71 \\
72\end{array}$ & $\begin{array}{l}9.0 \\
9.1\end{array}$ & $\begin{array}{l}2,800 \\
2,600\end{array}$ & $\begin{array}{l}63 \\
63\end{array}$ & $\begin{array}{l}160 \\
160\end{array}$ \\
\hline May 7, 1996 & $\begin{array}{l}0 \\
3.6\end{array}$ & $\begin{array}{l}125 \\
110\end{array}$ & $\begin{array}{l}25 \\
23\end{array}$ & $\begin{array}{l}13 \\
11\end{array}$ & $\begin{array}{l}75 \\
66\end{array}$ & $\begin{array}{l}9.2 \\
8.6\end{array}$ & $\begin{array}{l}3,000 \\
3,000\end{array}$ & $\begin{array}{l}130 \\
140\end{array}$ & $\begin{array}{l}160 \\
160\end{array}$ \\
\hline
\end{tabular}


Table 7. Concentrations of selected water-quality constituents in samples collected from lake sites, June 1995 through May 1996--Continued

[Water-quality analyses by the North Dakota Department of Health; $\mathrm{m}$, meters; 1 meter equals $3.25 \mathrm{feet;} \mathrm{mg} / \mathrm{L}$, milligrams per liter, $\mu \mathrm{g} / \mathrm{L}$, micrograms per liter, - , not determined; $<$, less than]

\begin{tabular}{|c|c|c|c|c|c|c|c|c|}
\hline Date & $\begin{array}{c}\text { Chloride, } \\
\text { total } \\
\text { (mg/L } \\
\text { as Cl) }\end{array}$ & $\begin{array}{l}\text { Nitrite plus } \\
\text { nitrate, } \\
\text { total } \\
\text { (mg/L as N) }\end{array}$ & $\begin{array}{c}\text { Ammonia, } \\
\text { total } \\
\text { (mg/L as } N \text { ) }\end{array}$ & $\begin{array}{c}\text { Organic } \\
\text { nitrogen, } \\
\text { total } \\
\text { (mg/L } \\
\text { as N) }\end{array}$ & $\begin{array}{c}\text { Ammonia } \\
\text { plus organic } \\
\text { nitrogen, } \\
\text { total } \\
\text { (mg/L as } N \text { ) }\end{array}$ & $\begin{array}{c}\text { Nitrogen, } \\
\text { total } \\
\text { (mg/L } \\
\text { as N) }\end{array}$ & $\begin{array}{l}\text { Phos- } \\
\text { phorus, } \\
\text { tota! } \\
\text { (mg/L } \\
\text { as P) }\end{array}$ & $\begin{array}{l}\text { Chloro- } \\
\text { phyll a } \\
(\mu g / L)\end{array}$ \\
\hline \multicolumn{9}{|c|}{ Site 1.-Continued } \\
\hline June 21, 1995 & $\begin{array}{c}10 \\
11 \\
11 \\
9.8\end{array}$ & $\begin{array}{r}0.139 \\
.152 \\
.149 \\
.098\end{array}$ & $\begin{array}{r}0.109 \\
.161 \\
.247 \\
.602\end{array}$ & $\begin{array}{l}0.99 \\
1.0 \\
.95 \\
.80\end{array}$ & $\begin{array}{l}1.1 \\
1.2 \\
1.2 \\
1.4\end{array}$ & $\begin{array}{l}1.3 \\
1.3 \\
1.3 \\
1.5\end{array}$ & $\begin{array}{r}0.106 \\
.133 \\
.116 \\
.180\end{array}$ & $\begin{array}{l}- \\
- \\
- \\
--\end{array}$ \\
\hline July 20, 1995 & $\begin{array}{l}9.9 \\
8.5 \\
9.0\end{array}$ & $\begin{array}{l}.006 \\
.007 \\
.028\end{array}$ & $\begin{array}{l}.042 \\
.079 \\
.411\end{array}$ & $\begin{array}{c}.95 \\
1.0 \\
.99\end{array}$ & $\begin{array}{l}1.0 \\
1.1 \\
1.4\end{array}$ & $\begin{array}{l}1.0 \\
1.1 \\
1.4\end{array}$ & $\begin{array}{l}.127 \\
.126 \\
.203\end{array}$ & $\begin{array}{r}68 \\
- \\
-\end{array}$ \\
\hline August 22, 1995 & $\begin{array}{l}15 \\
15\end{array}$ & $\begin{array}{l}.040 \\
.049\end{array}$ & $\begin{array}{l}.332 \\
.429\end{array}$ & $\begin{array}{l}.97 \\
.87\end{array}$ & $\begin{array}{l}1.3 \\
1.3\end{array}$ & $\begin{array}{l}1.3 \\
1.4\end{array}$ & $\begin{array}{l}.159 \\
.166\end{array}$ & $\begin{array}{r}10 \\
--\end{array}$ \\
\hline September 18, 1995 & $\begin{array}{l}4.6 \\
5.5\end{array}$ & $\begin{array}{l}.363 \\
.373\end{array}$ & $\begin{array}{l}.369 \\
.326\end{array}$ & $\begin{array}{l}.63 \\
.60\end{array}$ & $\begin{array}{c}1.0 \\
.93\end{array}$ & $\begin{array}{l}1.4 \\
1.3\end{array}$ & $\begin{array}{l}.226 \\
.227\end{array}$ & $\begin{array}{c}<3.0 \\
--\end{array}$ \\
\hline October 11, 1995 & $\begin{array}{l}5.8 \\
5.7\end{array}$ & $\begin{array}{l}.586 \\
.573\end{array}$ & $\begin{array}{l}.160 \\
.152\end{array}$ & $\begin{array}{l}.64 \\
.66\end{array}$ & $\begin{array}{l}.80 \\
.81\end{array}$ & $\begin{array}{l}1.4 \\
1.4\end{array}$ & $\begin{array}{l}.170 \\
.182\end{array}$ & $<3.0$ \\
\hline November 1, 1995 & $\begin{array}{l}7.1 \\
6.4\end{array}$ & $\begin{array}{l}.635 \\
.624\end{array}$ & $\begin{array}{l}.218 \\
.124\end{array}$ & $\begin{array}{l}.98 \\
.59\end{array}$ & $\begin{array}{c}1.2 \\
.72\end{array}$ & $\begin{array}{l}1.9 \\
1.3\end{array}$ & $\begin{array}{l}.139 \\
.139\end{array}$ & $\begin{array}{c}<3.0 \\
--\end{array}$ \\
\hline May 7, 1996 & $\begin{array}{l}5.8 \\
5.8\end{array}$ & $\begin{array}{l}.440 \\
.420\end{array}$ & $\begin{array}{l}.279 \\
.275\end{array}$ & $\begin{array}{l}.92 \\
.72\end{array}$ & $\begin{array}{l}1.2 \\
1.0\end{array}$ & $\begin{array}{l}1.7 \\
1.5\end{array}$ & $\begin{array}{l}.139 \\
.167\end{array}$ & $\begin{array}{c}<3.0 \\
--\end{array}$ \\
\hline \multicolumn{9}{|c|}{ Site 2.-Continued } \\
\hline July 20, 1995 & $\begin{array}{c}8.4 \\
9.4 \\
12\end{array}$ & $\begin{array}{r}0.006 \\
.009 \\
<.005\end{array}$ & $\begin{array}{r}0.068 \\
.083 \\
.199\end{array}$ & $\begin{array}{r}0.93 \\
.89 \\
.78\end{array}$ & $\begin{array}{l}1.0 \\
.97 \\
.98\end{array}$ & $\begin{array}{c}1.1 \\
.98 \\
.98\end{array}$ & $\begin{array}{r}0.125 \\
.101 \\
.137\end{array}$ & $\begin{array}{c}13 \\
-- \\
-\end{array}$ \\
\hline \multicolumn{9}{|c|}{ Site 3--Continued } \\
\hline June 21, 1995 & $\begin{array}{l}10 \\
9.8\end{array}$ & $\begin{array}{r}0.139 \\
.156\end{array}$ & $\begin{array}{r}0.167 \\
.238\end{array}$ & $\begin{array}{c}1.1 \\
.86\end{array}$ & $\begin{array}{l}1.3 \\
1.1\end{array}$ & $\begin{array}{l}1.4 \\
1.2\end{array}$ & $\begin{array}{r}0.127 \\
.133\end{array}$ & - \\
\hline July 20, 1995 & $\begin{array}{l}8.7 \\
9.3\end{array}$ & $\begin{array}{l}<.005 \\
<.005\end{array}$ & $\begin{array}{l}.097 \\
.103\end{array}$ & $\begin{array}{c}1.0 \\
.90\end{array}$ & $\begin{array}{l}1.1 \\
1.0\end{array}$ & $\begin{array}{l}1.1 \\
1.0\end{array}$ & $\begin{array}{l}.143 \\
.123\end{array}$ & $\begin{array}{c}<3.0 \\
--\end{array}$ \\
\hline August 22, 1995 & $\begin{array}{l}15 \\
10\end{array}$ & $\begin{array}{l}.035 \\
.042\end{array}$ & $\begin{array}{l}.272 \\
.375\end{array}$ & $\begin{array}{c}1.0 \\
.82\end{array}$ & $\begin{array}{l}1.3 \\
1.2\end{array}$ & $\begin{array}{l}1.4 \\
1.2\end{array}$ & $\begin{array}{l}.168 \\
.148\end{array}$ & $\begin{array}{c}35 \\
-\end{array}$ \\
\hline September 18, 1995 & $\begin{array}{l}4.7 \\
4.8\end{array}$ & $\begin{array}{l}.330 \\
.338\end{array}$ & $\begin{array}{l}.354 \\
.358\end{array}$ & $\begin{array}{l}.60 \\
.64\end{array}$ & $\begin{array}{c}.95 \\
1.0\end{array}$ & $\begin{array}{l}1.3 \\
1.4\end{array}$ & $\begin{array}{l}.226 \\
.216\end{array}$ & $\begin{array}{c}<3.0 \\
--\end{array}$ \\
\hline October 11, 1995 & $\begin{array}{l}6.3 \\
6.3\end{array}$ & $\begin{array}{l}.525 \\
.511\end{array}$ & $\begin{array}{l}.202 \\
.194\end{array}$ & $\begin{array}{l}.79 \\
.75\end{array}$ & $\begin{array}{l}.99 \\
.94\end{array}$ & $\begin{array}{l}1.5 \\
1.4\end{array}$ & $\begin{array}{l}.181 \\
.172\end{array}$ & $\begin{array}{c}<3.0 \\
--\end{array}$ \\
\hline November 1, 1995 & $\begin{array}{l}6.4 \\
6.2\end{array}$ & $\begin{array}{l}.677 \\
.665\end{array}$ & $\begin{array}{l}.109 \\
.090\end{array}$ & $\begin{array}{l}.57 \\
.67\end{array}$ & $\begin{array}{l}.67 \\
.76\end{array}$ & $\begin{array}{l}1.3 \\
1.4\end{array}$ & $\begin{array}{l}.150 \\
.148\end{array}$ & $\begin{array}{c}<3.0 \\
--\end{array}$ \\
\hline May 7, 1996 & $\begin{array}{l}8.3 \\
5.6\end{array}$ & $\begin{array}{l}.430 \\
.420\end{array}$ & $\begin{array}{l}.306 \\
.383\end{array}$ & $\begin{array}{c}.99 \\
1.2\end{array}$ & $\begin{array}{l}1.3 \\
1.6\end{array}$ & $\begin{array}{l}1.7 \\
2.0\end{array}$ & $\begin{array}{l}.126 \\
.135\end{array}$ & $\begin{array}{l}7.0 \\
--\end{array}$ \\
\hline
\end{tabular}

${ }^{1}$ Values for top of thermocline.

${ }^{2}$ Values for bottom of thermocline. 


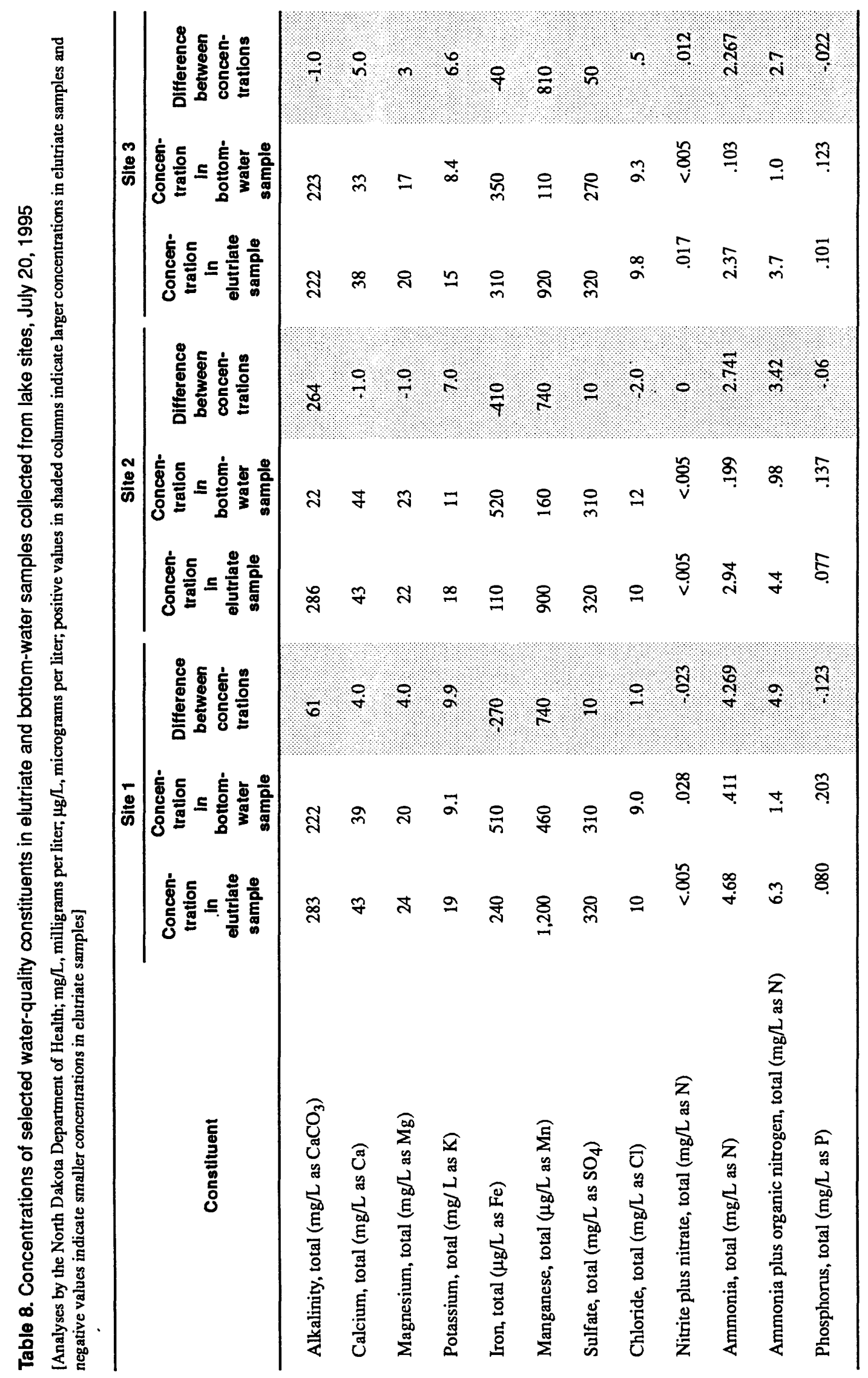


Total nitrite plus nitrate and total phosphorus concentrations in the elutriate samples differed little from the concentrations in the bottom-water samples. Ammonia concentrations in the elutriate samples were larger at all three sites, indicating large ammonia concentrations in the bed sediment. Ammonia is the by-product of the decomposition of organic matter in a lake, and the large ammonia concentrations in Patterson Lake could be attributed to decomposition of algal material and other aquatic plant life.

The analyses of the elutriate samples indicate a potential for ammonia concentrations in Patterson Lake to increase if the bed sediment becomes mixed with the lake water. Other constituent concentrations may increase or decrease, but the changes will not be as significant as an increase in ammonia concentrations. An increase in ammonia is important because, at times, the limited availability of nitrogen can limit algae growth in the lake; thus, additional nitrogen (in the form of ammonia) may increase algae production.

\section{SUMMARY AND CONCLUSIONS}

During June 1995 through May 1996, sediment, water-quality, physical-property, and streamflow data were collected from selected sites located in the E. A. Patterson Lake Basin. Specific objectives were to determine the suspended-sediment and total nutrient loads in major tributaries to Patterson Lake, including the loads entering, leaving, and remaining in the lake; determine the water-quality variations in Patterson Lake during the year; and evaluate the potential for nutrients and selected ions in lake sediments to be released back into lake waters.

The total suspended-sediment load entering Patterson Lake was 20,120 tons per year. The South Branch Heart River below Bull Creek Basin contributed about 60 percent of the total suspended-sediment load entering the lake. The suspended-sediment yield per basin for the South Branch Heart River near South Heart Basin was almost twice as much as the yield for the Heart River at South Heart Basin and much greater than the yield for the other gaged basins. In most of the suspended-sediment samples collected from the tributary sites, more than 90 percent of the sediment was less than 0.062 millimeter in particle size (silt and clay).

In bed-sediment samples collected from South Branch Heart River below Bull Creek and South Branch Heart River near South Heart, between about 75 and 78 percent of the sediment was less than 0.062 millimeter in particle size (silt and clay). In samples collected from Heart River at South Heart, North Creek near South Heart, and Ash Creek near South Heart, between about 44 and 47 percent of the sediment was greater than 1.00 millimeter in particle size (very coarse sand or larger).

The total nitrogen load entering Patterson Lake was 41.02 tons per year. Of the 41.02 tons per year, the Heart River at South Heart Basin contributed 32.48 tons per year (79.2 percent). The total phosphorus load entering the lake was 11.85 tons per year. Of the 11.85 tons per year, the Heart River at South Heart Basin contributed 9.32 tons per year ( 78.6 percent). The South Branch Heart River near South Heart Basin and the Ash Creek near South Heart Basin had the largest total nitrogen and total phosphorus yields per basin.

The total suspended-sediment load leaving Patterson Lake was 7,120 tons per year, and the load remaining was 13,000 tons per year. Thus, Patterson Lake had a sediment-trap efficiency of 65 percent. The total nitrogen load leaving the lake was 39.46 tons per year, and the load remaining was 1.56 tons per year (4 percent). The total phosphorus load leaving the lake was 5.57 tons per year, and the load remaining was 6.28 tons per year (53 percent). Analyses of suspended-sediment samples collected from the Heart River at State Avenue in Dickinson outflow site indicate that about 35 to 82 percent of the sediment leaving the lake is less than 0.062 millimeter in particle size. 
Water quality variations occurred in Patterson Lake during the year. Specific-conductance values decreased substantially from August to September 1995, indicating a dilution of the lake from runoff. $\mathrm{pH}$ values ranged from 6.7 to 8.4 and varied little among sites. Water temperatures reflected strong seasonal variability. The largest variation occurred during June 1995 in the deepest part of the lake, indicating that the lake was stratified with regard to temperature. Dissolved-oxygen concentrations near the lake bottom were less than 5 milligrams per liter during June and July and greater than or equal to 5 milligrams per liter (the amount needed for most fish) during the remainder of the year. Secchi-disk transparency ranged from 1.2 to 27 inches. The smallest values occurred during June and July 1995, which was when biomass material and sediment were visually observed in the lake.

Nitrogen and phosphorus, which are essential nutrients for plant growth, were present throughout Patterson Lake. All phosphorus concentrations were greater than 0.025 milligram per liter as $P$, indicating accelerated eutrophication could occur in the lake. The ratio of nitrogen to phosphorus was less than the 7:1 ratio ( 7 parts nitrogen to 1 part phosphorus) needed for healthy plants. However, most algae in the lake are able to fix nitrogen from the atmosphere and, thus, are not limited by the lower concentrations in the lake. Chlorophyll $a$ concentrations generally were larger during July and August and varied little among sites.

The analyses of the elutriate samples indicate a potential for ammonia concentrations in Patterson Lake to increase if the bed sediment becomes mixed with the lake water. Other constituent concentrations may increase or decrease, but the changes will not be as significant as an increase in ammonia concentrations. An increase in ammonia is important because, at times, the limited availability of nitrogen can limit algae growth in the lake; thus, additional nitrogen (in the form of ammonia) may increase algae production.

Water quality conditions in Patterson Lake are not unlike those in other North Dakota lakes. Additional study of basin and lake characteristics not addressed in this report may be necessary to help evaluate particular management techniques that might contribute to improved water-quality conditions in Patterson Lake.

\section{REFERENCES}

Carlson, R.E., 1977, A trophic state index for lakes: Limnology and Oceanography, v. 22, p. 361-369.

Guy, H.P., 1969, Laboratory theory and methods for sediment analysis: U.S. Geological Survey Techniques of Water-Resources Investigations, book 5, chap. $\mathrm{C} 1,58 \mathrm{p}$.

Guy, H.P., and Norman, V.W., 1970, Field methods for measurement of fluvial sediment: U. S. Geological Survey Techniques of Water-Resources Investigations, book 3, chap. C2, 59 p.

Haffield, N.D., 1981, Statistical summaries of streamflow and water-quality data for streams of western North Dakota, 1977-80: U.S. Geological Survey Open-File Report 81-1066, 78 p.

Harkness, R.E., Haffield, N.D., Berkas, W.R., Norbeck, S.W., and Strobel, M.L., 1995, Water resources data, North Dakota, water year 1994: U. S. Geological Survey Water-Data Report ND-94-1, 466 p.

1996, Water resources data, North Dakota, water year 1995: U. S. Geological Survey Water-Data Report ND-95-1, 534 p.

Lest, L.H., 1995, Dickinson Dam Edward Arthur Patterson Lake 1991 sedimentation study: Bureau of Reclamation, $55 \mathrm{p}$. 
Maderak, M.L., 1966, Sedimentation and chemical quality of surface water in the Heart River Drainage Basin, North Dakota: U.S. Geological Survey Water-Supply Paper 1823, 42 p.

North Dakota State Department of Health and Consolidated Laboratories, 1991, Standards of water quality for State of North Dakota: Rule 33-16-02: Bismarck, North Dakota, 29 p.

Porterfield, George, 1972, Computation of fluvial-sediment discharge: U.S. Geological Survey Techniques of WaterResources Investigations, book 3, chap. C3, 66 p.

Rantz, S.E., and others, 1982, Measurement and computation of streamflow--volume 2, Computation of discharge: U.S. Geological Survey Water-Supply Paper 2175, 631 p.

U.S. Department of Commerce, National Oceanic and Atmospheric Administration, Environmental Data Service, 1950-97, Climatological data, North Dakota, Annual summaries, 1949-96: Asheville, North Carolina, v. 58-105, no. 13, unpaginated.

U.S. Environmental Protection Agency, 1986, Quality criteria for water: Office of Water Regulations and Standard, Washington, D.C., EPA 440/5-86-001, unpaginated.

U.S. Geological Survey, 1993, National water summary 1990-91--Stream Water Quality: U.S. Geological Survey Water-Supply Paper 2400, p. 429-436.

Wetzel, R.G., 1983, Limnology (2nd ed.): Philadelphia, W. B. Saunders Company, 858 p.

Williams-Sether, Tara, Macek-Rowland, K.M., and Emerson, D.G., 1994, Climatic and hydrologic aspects of the 1988-92 drought and the effect on people and resources of North Dakota: North Dakota State Water Commission Water Resources Investigation 29, $57 \mathrm{p}$. 